\title{
Role expectations and predictions of trends for human resource development at large public universities within the Southern Regional Education Board (SREB) area
}

\author{
Drayton Ray Justus Jr. \\ West Virginia University
}

Follow this and additional works at: https://researchrepository.wvu.edu/etd

\section{Recommended Citation}

Justus, Drayton Ray Jr., "Role expectations and predictions of trends for human resource development at large public universities within the Southern Regional Education Board (SREB) area" (1999). Graduate Theses, Dissertations, and Problem Reports. 3131.

https://researchrepository.wvu.edu/etd/3131

This Dissertation is protected by copyright and/or related rights. It has been brought to you by the The Research Repository @ WVU with permission from the rights-holder(s). You are free to use this Dissertation in any way that is permitted by the copyright and related rights legislation that applies to your use. For other uses you must obtain permission from the rights-holder(s) directly, unless additional rights are indicated by a Creative Commons license in the record and/ or on the work itself. This Dissertation has been accepted for inclusion in WVU Graduate Theses, Dissertations, and Problem Reports collection by an authorized administrator of The Research Repository @ WVU.

For more information, please contact researchrepository@mail.wvu.edu. 
Role Expectations and Predictions of Trends for Human Resource Development at Large Public Universities within the Southern Regional Education Board (SREB) Area

Drayton Ray Justus, Jr.

Dissertation submitted to the College of Human Resources and Education at West Virginia University in partial fulfillment of the requirements for the degree of

Doctor of Education in

Educational Leadership

Ernest R. Goeres, Ph.D., Chair Scott C. Kelley, Ed.D.

Thomas Sloane, Ph.D.

Floyd L. Stead, Ed.D.

David G. Williams, Ph.D.

Department of Advanced Educational Studies

Morgantown, West Virginia

1999 


\section{ABSTRACT \\ Role Expectations and Predictions of Trends for Human Resource Development at Large Public Universities within the Southern Regional Education Board (SREB) Area}

Drayton Ray Justus, Jr.

This study was designed to identify the role expectations, reporting hierarchy, years in role and trends in human resource development as reported by the person responsible for human resource development in large public universities within the Southern Regional Education Board (SREB) geographic area. The population for this study was all the fouryear public universities in Southern Regional Education Board states which were classified by 1997 SREB-State Data Exchange definitions as SREB I $(n=26)$.

Each institution in the sample was mailed a copy of the Human Resource Development (HRD) Roles Survey, an instrument developed for the purpose of this research. The instrument was based on data from the American Society for Training and Development (ASTD) delineations as outlined in the Models for HRD Practice (McLagan \& Suhadolnik, 1989). The total return rate for the study was $76.9 \%(\mathrm{n}=20)$.

Results of the study found that the greatest average institutional emphasis for the respondents was on those roles involving the delivery and support of existing HRD programs and services; the least average institutional emphasis was on roles involving assisting individual employees with their developmental needs, determining organizational needs, evaluating existing programs, and identifying new programs to meet changing needs.

Regarding future trends, respondents predicted growth in overall human resource responsibilities, an increase in the number of training and development programs, more HRD involvement in strategic planning, an increase in organization and workforce change, and continued advancing technology and resulting new concepts.

In summary, there is a determination that an inconsistency exists in strategic utilization of the human resource development function among the institutions surveyed, and a recognition by the respondents that a continued shift in role emphasis must occur to meet changing institutional needs. This study provides baseline data from which to assess the role of HRD in higher education and seeks to add to minimal existing research on how to utilize human resources to improve effectiveness of large public universities. 


\section{Acknowledgments}

The author is indebted to many individuals for their assistance, guidance, and inspiration throughout the course of this study. Sincere appreciation is extended to members of the author's doctoral committee: Dr. Scott C. Kelley, Dr. Thomas S. Sloane, Dr. Floyd L. Stead, Dr. David G. Williams, and especially Dr. Ernest R. Goeres, who served as committee chairman and also provided excellent guidance and much-needed assistance during those times when I struggled to overcome inertia.

Very special acknowledgement is due Dr. Stead, who provided invaluable suggestions and assistance regarding clarity in writing, accuracy of content, and presentation of statistical material. His encouragement and friendship were key factors in the completion of this study.

A special gratitude is extended to Dr. Kelley, who is my immediate superior on the West Virginia University administrative team, and has continuously supported and encouraged me in this endeavor. Sincere thanks also go to Melanie Mills for her secretarial assistance. Another colleague, Dr. Richard Phalunas, deserves much credit for the persistent, but friendly urging and support which have contributed to getting the job done.

It seems fitting to save the best for last. Undoubtedly, the greatest sacrifices and the most encouragement during the long hours of preparing this material have come from my loving wife and best friend; this one's for you, Sue Ann! 


\section{TABLE OF CONTENTS}

PAGE

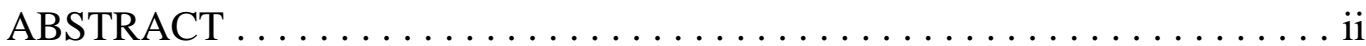

ACKNOWLEDGEMENTS $\ldots \ldots \ldots \ldots \ldots \ldots \ldots \ldots \ldots$ iii

LIST OF TABLES $\ldots \ldots \ldots \ldots \ldots \ldots \ldots \ldots \ldots \ldots \ldots \ldots$ viii

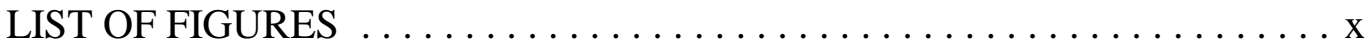

\section{CHAPTER}

1 Introduction $\ldots \ldots \ldots \ldots \ldots \ldots \ldots \ldots \ldots \ldots \ldots \ldots \ldots \ldots \ldots \ldots \ldots$

Background $\ldots \ldots \ldots \ldots \ldots \ldots \ldots \ldots \ldots \ldots \ldots \ldots \ldots \ldots \ldots$

Statement of the Problem $\ldots \ldots \ldots \ldots \ldots \ldots \ldots \ldots \ldots$

Justification/Need for the Study $\ldots \ldots \ldots \ldots \ldots \ldots \ldots$

Limitations of the Study $\ldots \ldots \ldots \ldots \ldots \ldots \ldots \ldots$

Definitions of Terms $\ldots \ldots \ldots \ldots \ldots \ldots \ldots \ldots$

2 Review of Related Literature $\ldots \ldots \ldots \ldots \ldots \ldots \ldots \ldots \ldots$

History of Human Resources $\ldots \ldots \ldots \ldots \ldots \ldots \ldots$

Early Development of Human Resource Functions . . . 12

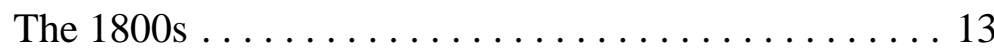

The Early 1900 s . . . . . . . . . . . . . . . . . 14

The Mid-to-Late $1900 \mathrm{~s}$. . . . . . . . . . . . . . 17

Theory ............................. 19

Scientific Management Theories ........... 20 
$\underline{\text { PAGE }}$

Human Relations Theories ................ 20

Motivation Theories .....................21

Managerial Styles $\ldots \ldots \ldots \ldots \ldots \ldots \ldots \ldots \ldots 22$

Systems Theory $\ldots \ldots \ldots \ldots \ldots \ldots \ldots \ldots \ldots 24$

Roles of Human Resource Development . . . . . . . . . . 26

Models for Excellence .................. 28

Models for HRD Practice . . . . . . . . . . . . . . . 29

Trends in Human Resource Development . . . . . . . . . . 31

Models for HRD Practice . . . . . . . . . . . . . . 32

Human Resources in Higher Education . . . . . . . . . . . . . 34

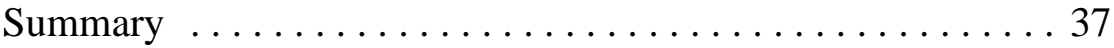

3 Research Methods, Procedures, and Demographics ........... 38

Population and Sample $\ldots \ldots \ldots \ldots \ldots \ldots \ldots \ldots . \ldots . \ldots . \ldots$

Survey Instrument $\ldots \ldots \ldots \ldots \ldots \ldots \ldots \ldots \ldots \ldots \ldots$

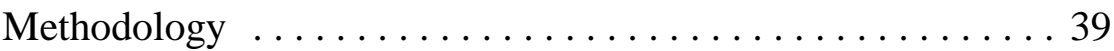

Analysis of Data ........................... 40

Survey Response $\ldots \ldots \ldots \ldots \ldots \ldots \ldots \ldots \ldots \ldots$

Institutional Demographic Data . . . . . . . . . . . . . 41

Individual Demographic Data $\ldots \ldots \ldots \ldots \ldots \ldots \ldots$

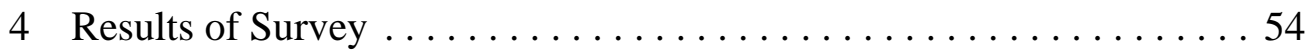

Analysis of HRD Roles $\ldots \ldots \ldots \ldots \ldots \ldots \ldots \ldots . \ldots . \ldots . \ldots 4$

Analysis of HRD Trends $\ldots \ldots \ldots \ldots \ldots \ldots \ldots \ldots$ 


\section{$\underline{\text { PAGE }}$}

Major Findings . . . . . . . . . . . . . . . . 68

Question $1 \ldots \ldots \ldots \ldots \ldots \ldots \ldots 68$

Question $2 \ldots \ldots \ldots \ldots \ldots \ldots \ldots \ldots, \ldots 9$

Question $3 \ldots \ldots \ldots \ldots \ldots \ldots \ldots \ldots \ldots \ldots$. 71

Question $4 \ldots \ldots \ldots \ldots \ldots \ldots \ldots \ldots \ldots \ldots$

Question $5 \ldots \ldots \ldots \ldots \ldots \ldots \ldots \ldots \ldots \ldots$

Ancillary Findings $\ldots \ldots \ldots \ldots \ldots \ldots \ldots \ldots \ldots$

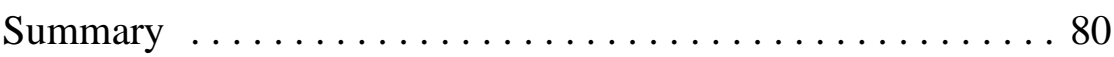

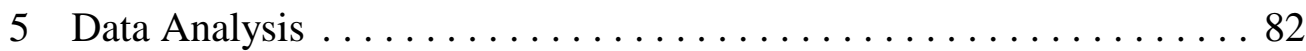

Research Questions ...................... 82

Ancillary Findings $\ldots \ldots \ldots \ldots \ldots \ldots \ldots \ldots$

The 1997 Triplett Study . . . . . . . . . . . . . . . . . . . 89

Difficulty in Defining HRD ................... 90

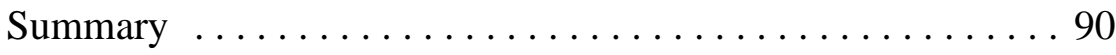

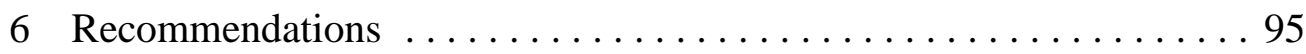

For Institutions and Practitioners . . . . . . . . . . . . 95

For Further Study $\ldots \ldots \ldots \ldots \ldots \ldots \ldots \ldots$

Researcher's Insights $\ldots \ldots \ldots \ldots \ldots \ldots \ldots \ldots \ldots \ldots$

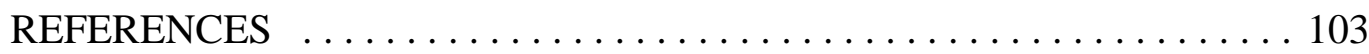

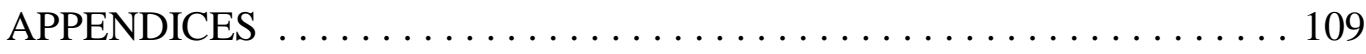

A ... List of SREB I Institutions ..................... 110 


\section{$\underline{\text { PAGE }}$}

B ... Human Resource Development (HRD)

Roles Survey Instrument . . . . . . . . . . . . . . . . 112

C . . Cover Letter to Chief Human Resources Officers ........ . 115

D ... List of Institutions Responding to Survey ............ 117

E ... The Human Resource Wheel ...................... 119

F . . ASTD Permission to Reprint the Human Resource Wheel . . . 121

G . . Responses to Survey Question \#27 . . . . . . . . . . . 123 


\section{List of Tables}

$\underline{\text { Table }} \underline{\text { Page }}$

1. Survey Population and Return by State $\ldots \ldots \ldots \ldots \ldots \ldots$

2. Total Enrollments (Headcount) $\ldots \ldots \ldots \ldots \ldots \ldots \ldots \ldots \ldots$

3. Total Number of Employees (Headcount) . . . . . . . . . . . . 44

4. Annual Budget (FY98 Educational and General Expenses) . . . . . . 45

5. Job Title of Person in HRD Role . . . . . . . . . . . . . 47

6. Distribution of Number of Years in HRD Role . . . . . . . . . . . . 48

7. Gender of Respondents $\ldots \ldots \ldots \ldots \ldots \ldots \ldots \ldots \ldots \ldots \ldots$

8. Highest Educational Level Attained by Respondents . . . . . . . . . 49

9. Major in Highest Educational Level Attained by Respondents . . . . . . 50

10. Job Title of Person to whom HRD Reports $\ldots \ldots \ldots \ldots \ldots \ldots \ldots$

11. Percent of Responsibilities Assigned to HRD Role . . . . . . . . . . 52

12. Responsibilities in Addition to HRD ............... 53

13. Summary of Institutional Emphasis Placed Upon HRD Roles . . . . . . 57

14. Institutional Emphasis Upon HRD Roles

By Respondent's Years in HRD $(0-12$ Years $) \ldots \ldots \ldots \ldots . . .58$

15. Institutional Emphasis Upon HRD Roles

By Respondent's Years in HRD $(13+$ Years $)$. . . . . . . . . 59

16. Institutional Emphasis Upon HRD Roles

By Percent of Respondent's Responsibilities Assigned to

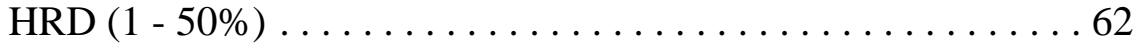

17. Institutional Emphasis Upon HRD Roles

By Percent of Respondent's Responsibilities Assigned to

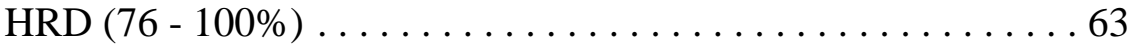


18. Frequency Distribution of Expectation for Increase/Decrease

In Emphasis Placed Upon HRD Roles By the Year 2010 . . . . 66

19. Emergent Category Analysis for Predicted Changes in HRD . . . . . . 67

20. Organizational Level to which HRD Reports . . . . . . . . . . 69

21. Institutional Emphasis Placed Upon HRD Roles by Organization Level to which HRD Reports (First and Second Level) . . . . . 73

22. Institutional Emphasis Placed Upon HRD Roles by Organization Level to which HRD Reports (Third and Fourth Level) . . . . . 74

23. Summary of Institutional Emphasis Placed Upon HRD Roles By Gender of Respondents . . . . . . . . . . . . 78

24. Summary of Predicted Change in Emphasis Upon HRD Roles By Gender of Respondents . . . . . . . . . . . . . 80

25. Organizational Level to which HRD Reports Compared to Respondent's Percent of Responsibilities Assigned to HRD . . 85 


\section{List of Figures}

Figure $\quad \underline{\text { Page }}$

1. Role Emphasis By Years In HRD $\ldots \ldots \ldots \ldots \ldots \ldots \ldots \ldots \ldots \ldots$

2. Role Emphasis By Percent Assigned to HRD . . . . . . . . . . . 64

3. Role Emphasis By Organizational Level . . . . . . . . . . . . . . 75

4. Role Emphasis By Gender . . . . . . . . . . . . . . . . . . 79 


\section{Chapter 1}

\section{Introduction}

\section{Background}

Over the last few decades, advances in communications, technology, mobility and competition have changed the way people live and work. These changes continue to accelerate and are causing significant restructuring of the workforce and both the missions and modus operandi of organizations within our society (Mirvis, 1993). Higher education has not been immune to the influences of these demographic and cultural shifts and faces its own set of pressures from these external forces. Twenty-two higher education leaders participated in the Pew Higher Education Roundtable in 1993 and outlined how their institutions were being shaped by this complex mix of external changes. As part of the Pew program, roundtable participants recounted that reductions in funding, changing student profiles, a demand for increased quality and service, the explosion of new technologies and the increase in consumerism have influenced higher education and have been the external impetus for internal change. Higher education is facing its most severe outcry of public criticism and calls for reform (Pew, 1993).

In order to compete in the global economy, and to achieve the new objectives, the workplace is rapidly shifting from hierarchies to team structures, from large to smaller units, from control to empowerment, and from an emphasis on the trainer to an emphasis on the learner (Mirvis, 1993). The literature is consistent in its prediction that continuous learning will receive increased priority from management in the changing workplace. Drucker states that institutions of higher education are learning that continuing education of already highly educated adults is not a luxury, or simply to 
generate additional money, or good public relations; it is, rather, becoming a central thrust of our knowledge society, so those institutions are organizing themselves and their faculties to attract doctors, engineers and executives who want and need to go back to school (Drucker, 1990).

A study conducted for the American Society for Training and Development (ASTD) and the U. S. Department of Labor in 1990 determined that competitive organizations in the future will be those which create cultures for workers to learn and to solve complex problems. One aspect of the changing workplace is the increasing emphasis upon systems-wide thinking and integration of knowledge. Modern day theorists are questioning the value of specialization and fragmentation promoted during the industrialage. Again, there is consistency in the literature in predicting that continuous learning and systems thinking will receive priority in the new workplace (Brinkerhoff \& Gill, 1994). Moreover, an increased focus on organizational learning, empowerment, integration, teams, and employee development will have major consequences for the work of human resource professionals (Jackson \& Shuler, 1995).

Prior to the Industrial Revolution, "personnel work," whether in business or in educational institutions, was a paperwork and support function primarily concerned with processing people and paper. It did not become a managerial specialty until the late 1800s when business was impacted by unionization of workers and adaptation of scientific management principles. The 1950s brought behavioral science into the workplace, and human resources development began to be recognized as a meaningful endeavor. The term "human resources" did not come into common use until the 1970s; many accepted the term simply as a synonym for the term "personnel," while others 
recognized "human resources" as an umbrella term for two separate functions: personnel administration and human resource development. Human resource management (personnel administration) includes the determination of positions, benefits and compensation structure, employee recruitment and evaluation, and the development of policies and processes required to administer equitable employment terms, while human resource development (HRD) functions traditionally encompass identifying employee and workplace needs, designing and delivering education and training programs, and evaluating results (Fortunato, Greenburg \& Waddell, 1987).

On the college or university campus, personnel administration was one of the lastareas to become a specialty function; personnel administrators in higher education didnot have a formal inter-campus meeting until 1947, the year of the origin of the College and University Personnel Association (CUPA). Even with the growing importance of human resource development as a facet of the overall function, the traditional campus human resources department has generally maintained five rather welldefined areas of endeavor, four of which can be accurately defined as human resource management: (1) staff employment, which includes recruiting, testing, selecting and placement; (2) employee benefits, including paid leave programs, health and life insurance, retirement, Unemployment and Workers Compensation; (3) staff job classification and compensation, including job description review and salary plan structure, and may or may not include payroll processes; (4) employee relations, including union relations, disciplinary policy, performance evaluation and grievance procedures; and (5) employee training and development. With the exception of employee benefits (and payroll, if organizationally included under Human Resources), these functions do 
not generally serve faculty; usually, faculty governance and related policies are handled through the offices of the provost and deans of the schools and colleges.

The focus of this study has been on the role expectations and trends in employee training and development and closely related human resource development activities within the defined group of organizations. Three major studies to define the human resource development field have been sponsored by the American Society for Training and Development (ASTD). The first empirical study of human resource development, $\underline{A}$ Study of Professional Training and Development Roles and Competencies (1978), was based upon survey results from 3,000 human resource development (HRD) professionals and resulted in the identification of 14 major activities of human resource practitioners. A second study, Models for Excellence (1983), identified 15 key roles and 102 work outputs performed in human resource development work. The third competency study, Models for HRD Practice, was conducted in 1989, and is the basis for the current definition of roles held by human resource professionals (Rothwell \& Sredl, 1992).

Models for HRD Practice defines eleven roles which are linked to competencies and outputs. The key HRD outputs by role as identified in the 1989 ASTD competency study are defined as follows: (a) administrator, (b) evaluator, (c) HRD manager, (d) HRD materials developer, (e) individual career-development advisor, (f) instructor or facilitator, (g) marketer, (h) needs analyst, (i) organization change agent, (j) programdesigner, and $(\mathrm{k})$ researcher (McLagan, 1989).

The key roles define the functions which experts predict will be important for human resource development work in the next decade and beyond. Practices related to 
human resources work continue to evolve as the workplace undergoes changes, and it becomes increasingly important to optimize the performance of individuals, teams and entire organizations. Moreover, the labor intensity of higher education indicates a critical role for human resources professionals in colleges and universities; salaries account for $80-85 \%$ of institutional budgets, and the field experiences a high rate of turnover. In spite of this, literature about the role of human resources in United States higher education is very limited. A report of the Study Group on Restructuring commissioned by the Pew Higher Education Research Program indicates a lack of models for higher education restructuring, and that most of the reengineering work has been on the administrative side of higher education and not system-wide (Pew Higher Education Research Program, 1993). Jackson and Schuler (1995) called for "research that identifies and describes theconfiguration of human resource management systems" to serve as a foundation for future research. The human resource profession is being challenged to reinvent itself, and further study is necessary to determine the current status of human resource development within our higher education institutions. There has been a proliferation of material on specific aspects of personnel management and human resource development in general; however, the nature of such activity at higher education institutions has largely been ignored. In 1997, Beth Triplett submitted the doctoral dissertation, Role Expectations and Predictions of Trends for Human Resource Development at Small, Private Colleges and Universities Within the Southern Regional Education Board Area, at West Virginia University. The purpose of my study was to provide a similar review of the large public universities within the SREB, with minor modifications to the methodology based on Triplett's recommendations for further study. 


\section{Statement of the Problem}

The purpose of this investigation was to identify the functions expected and performed by the person(s) responsible for human resource development in large, public universities within the Southern Regional Education Board (SREB) area. Specifically, the following questions were addressed:

1. What is the reporting hierarchy for the person(s) responsible for human resource development functions?

2. What functions are expected to be performed by the human resource development person(s)?

3. To what extent do the institutions place emphasis upon specific human resource development functions/roles?

4. What changes in emphasis does the human resource development person(s) expect for the identified roles of human resource development at the institution in the next decade?

5. What specific changes in human resource development are expected to occur at the institution by the year 2010 ? 


\section{Justification/Need for the Study}

Almost all administrators have some human resources management responsibilities, but those activities which, over time, have required special attention, preparation, and expertise became the responsibility of the human resource (personnel) professional. Certainly, human resource development is recognized as a specialized and meaningful endeavor. There has been considerable literature addressing the status and trends of human resource development (HRD) in business and industry; however, there is much less information to be found regarding HRD efforts (not to be confused with student development) within institutions of higher education.

Higher education human resource professionals can use the results of this study to increase their understanding of how their work and expectations align with others at similar institutions. A greater understanding of the human resources area can be of benefit across campus, since some human resources responsibilities are shared by all administrators within an institution. University presidents will benefit from an increased understanding of the roles and status of human resource development, allowing them to incorporate into their strategic thinking new ideas about how their institutions should act and react, and the role that both human resource development professionals and employees in general can perform on campus. Deans and department chairpersons can find the results of this study to be of assistance as they design and coordinate faculty development activities. Higher education administration faculty may be able to incorporate results of this study into their teaching of future human resource professionals as they prepare them for their changing role on the college or university campus. Hopefully, thousands of employees at the universities themselves will be positively 
affected as the enhancement of human resource development on campus provides the employee with increased opportunity for meaningful participation and professional growth. The results of the study may be of benefit outside the university as well; professional associations, such as the College and University Personnel Association, the Society for Human Resource Management and the American Society for Training and Development, could utilize the information to benefit their members and expand those organizations' understanding of the profession as a whole.

Triplett (1997) determined that HRD activities were limited at small private colleges and universities within the SREB. In concluding her study, she recommended that the study be replicated for larger institutions. This study can provide certain comparisons, but is not a true replication because the survey instrument was modified, and the population/sample was changed to reflect the large, public universities (SREB I) within the Southern Regional Education Board area.

\section{Limitations of the Study}

This study faced five key limitations:

1. The study was limited to the perceptions of the human resource development administrator.

2. There was possible respondent bias (Kerlinger, 1986) in self-reporting perceptions on the survey.

3. There was possible respondent bias due to hierarchal differences in the location of the human resource development function at respondents' institutions.

4. There was possible respondent bias due to researcher's initial telephone 
discussions with respondents regarding specific definitions of HRD roles.

5. There was possible respondent bias due to difficulty in defining human resource development functions and making clear distinctions between human resource development and human resource management (see Chapter 5, p. 90). 


\section{Definitions of Terms}

Human resources development - The integrated use of training and development, organization development, and career development to improve individual, group and organizational effectiveness (McLagan, 1989) (see Appendix D).

$\underline{S R E B}$ - The Southern Regional Education Board, which includes the following fifteen states: Alabama, Arkansas, Florida, Georgia, Kentucky, Louisiana, Maryland, Mississippi, North Carolina, Oklahoma, South Carolina, Tennessee, Texas, Virginia and West Virginia.

Large public universities - All public, four-year institutions (see Appendix A) that are classified by 1997 SREB-State Data Exchange definitions as:

SREB I: Institutions awarding at least 100 doctoral degrees which are distributed among at least 10 CIP (Classification of Instructional Programs) categories (2-digit classification) with no more than 50 percent in any one category,

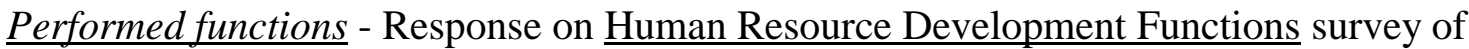
self-assessment by human resources development person of emphasis placed by institution upon selected roles as defined by the 1989 American Society for Training and Development competency study, Models for HRD Practice.

Expected functions - Categories of functions as determined by the roles defined by the 1989 ASTD competency study, Models for HRD Practice, as indicated by institutional requirements for the human resource development person(s). 


\section{Chapter 2}

\section{Review of Related Literature}

This chapter presents a review of selected literature which is related to the history of human resource development as a field of endeavor, the evolution of major theories pertaining to the field, and the role of human resource development in higher education. The first section of the chapter outlines the relevant history. The second section summarizes selected literature related to management theory, organization behavior and systems thinking. The third section details the roles of human resource development as they relate to the objectives of this study. Section four delineates future trends predicted for human resources by the literature reviewed, and section five reviews human resource development in the higher education environment.

\section{History of Human Resources}

McLagan defined human resource development as the "integrated use of training and development, organization development and career development to improve individual, group and organizational effectiveness" (McLagan, 1989). Recruitment, training and performance review have been in existence, in one form or another, since primitive times; cavemen and other uncivilized people were likely to have carried out the essential components of human resource development long before they became refined as the organizational theory and practice known today (Nadler, 1984).

Human Resources is an umbrella term for two separate functions: personnel administration and human resource development (Fortunato, Greenburg, \& Weaddel, 1987). The term "human resources" did not come into common use until the 1970s, at 
which time it became a synonym for the term "personnel" (Singer, 1990). Personnel administration, or human resource management includes the determination of positions, benefits and compensation structure, employee recruitment and evaluation, and the development of policies and processes required to administer equitable employment terms; human resource development functions traditionally encompass identifying employee and workplace needs, designing and delivering education and training programs and evaluating results (Fortunator, Greenburg, \& Weaddel, 1987). The term "human resources" was referenced by theorists in 1958, but "human resource development" as a term was not coined until 1968 by Leonard Nadler (Rothwell \& Sredl, 1992).

\section{Early Development of Human Resource Functions}

Human resource development has been in existence, in some form, since the Stone Age as one person trained the other to make spears, arrows, or other weapons (Nadler, 1984). The Bible cites examples of certain slaves being given special responsibilities, and there are indications that a division of labor occurred among gladiators, hunters and tribal members (Singer, 1990). As early as 2000 B.C., the Babylonian Code of Hammurabi outlined rules and procedures for transferring skills from experienced workers to youth (Craig, 1996; Rothwell \& Sredl, 1992).

Personnel became a managerial specialty in the late 1800s when business was being affected by the Industrial Revolution, the unionization of workers, the adaptation of scientific management principles, and the advent of war (Singer, 1990). Prior to that time, training or human resource development occurred on an individual basis in most situations instead of being institutionalized. Very often, this training evolved into a 
"shadowing" experience, and eventually the on-the-job education became formalized into an apprentice program (Nadler, 1984). There was also evidence that the American Indians engaged in apprenticeship activities to convey the art of pottery making, construction of framed cliff dwellings, and commerce (Nadler, 1970).

Several large organizations such as the military, churches and governments also engaged in more formalized human resource development activities. Guilds were created to impose standards of quality and differentiated work levels for the trades. Between the twelfth and fifteenth century, the evolution of the journeyman position led to the creation of yeomandry guilds, which became the precursors to modern-day labor unions. The guild system and self-directed training served the economy of the day quite well, but individual coaching was not sufficient to meet the needs of a growing, industrialized nation (Craig, 1976).

The 1800s

The Industrial Age brought with it the advent of new technology which made the old apprenticeship system inadequate. Veteran workers didn't have experience with the new machinery and methods, and they were, therefore, unable to teach their skills to the new workers. The situation was made even worse by a predominantly illiterate workforce including slaves (Rothwell \& Sredl, 1992).

In response to industry's demand for workers and to meet the need for job skill training, schools were established to teach the mechanical arts. The majority of employee pre-skill needs were met through these institutions or on an individual basis, but formalized human resource development functions were still scarce (Nadler, 1970). 
Developing technology and industry, however, forced larger organizations to establish "factory schools" to teach on-the-job skills as early as 1872 (Craig, 1996). The YMCA began to offer trade training in 1862, and by 1905 was offering over 60 courses in commercial and industrial areas (Rothwell \& Sredl, 1992).

At about the turn of the century, there were several developments involving colleges and universities in the vocational training area. The Morrill Act of 1862 created land grant colleges, involving higher education as a partner to respond to increased educational needs to meet advances in agriculture and mechanization (Nadler, 1984). County Extension Agents evolved from the land grant colleges, and these individuals performed many of the human resource development functions for farmers. Higher Education also helped train workers through a cooperative education program, combining on-the-job experience with formal education. This program came about in 1906, initially at the University of Cincinnati, to prepare engineers for the practical world of work (Nadler, 1970; Rothwell \& Sredl, 1992).

\section{The Early 1900s}

Employers were beginning to depend on formal training to meet their production needs, and also to increase workers' efficiency by utilizing the scientific management theories of Frederick Taylor and Frank and Lillian Gilbreth. Psychologist Hugo Munsterberg's work of applying scientific management principles to business formed the foundation for the use of testing in employee selection, and was a forerunner of early human resource development functions. Munsterberg's 1913 work at the Boston Elevated Railway Company was furthered by the Army Alpha and Beta tests, which were 
used for military inductions. These instruments precipitated early group selection processes and testing (Singer, 1990; Rothwell \& Sredl, 1992).

World War I brought with it an unprecedented emphasis on human resources through an increased demand for production and the displacement of skilled workers into the military. The war effort produced the first national recognition of the contribution that human resource development could make to the workplace and the realization that work-related activities could be taught quickly and effectively (Nadler, 1984; Singer, 1990).

During World War I and continuing into the 1920s, many personnel departments were established as a function to address employee welfare concerns. Employee welfare secretaries were hired to meet personal needs of employees and thwart the interest in unionization. The decade of the 1920s brought a period of prosperity, and there was less demand for a time on human resources to boost employee morale or provide training; industrial leaders were more concerned with production than meeting the needs of individuals and often hired consultants to focus on increasing efficiencies (Nadler, 1970 $\& 1984)$

In 1923, a major research study was conducted at the Hawthorne, Illinois, plant of the Western Electric Company to examine the effects of lighting on worker productivity. The Hawthorne Study concluded that employee attitudes and their perceptions about management attitudes toward them had more to do with productivity than the physical interventions imposed by the researchers. The conclusions from this study became the basis for the field of industrial psychology and led to the development of the human relations movement (Nadler, 1970 \& 1984; Singer, 1990). 
The Great Depression of the 1930s brought a waning of importance for human resource development; there was an abundance of laborers willing to work and company resources were severely limited. Cost reduction efforts eliminated jobs and decreased the benefits provided to employees. Passage of the Norris-LaGuardia Act of 1932 and the Wagner Act of 1935 brought a dramatic increase in the number of unionized workers; as a further result, personnel activities in business shifted from a major focus on productivity to one of labor relations. Human resource efforts and training programs were then implemented primarily through government sponsored programs. The Bureau of Apprenticeship and Training was established in 1934 and combined with the government work programs to provide not only jobs, but workplace skills to the large number of people who were unemployed (Nadler, 1970 \& 1984; Singer, 1990).

Even after the Great Depression had ended, government personnel and job training programs continued. The Job Instruction Training (JIT) program was instituted by the War Manpower Commission. This program reformed the on-the-job training approach and targeted first and second-line supervisors in management and human relations skills. Success of the JIT program led to development of other "J programs," as they were called: the Job Relations Training, Job Methods Training, and Job Safety Training programs (Rothwell \& Sredl, 1992). Industry and government leaders learned that employees could be trained and that supervisors could be given the responsibility to train new employees (Nadler, 1970).

Due to their companies' immediate need for skilled workers, many executives were stimulated to a heightened interest in training by World War II. Since the men who comprised the traditional labor force were now unavailable due to the draft, other sources 
of labor were entering the workforce. Women, men over 40 (now with obsolete skills), and handicapped workers were now much more in demand by employers willing to train them (Nadler, $1970 \& 1984)$.

The proliferation of training programs created a need for people to administer and supervise these activities. As more industrial training directors were hired, local and state organizations were developed as a mechanism to share problems and resources. The National Society of Sales Training Executives was organized in 1940, and the National Association of Foremen provided the opportunity for training directors to exchange ideas (Craig, 1976). In 1942, several local organizations of training specialists merged to become the American Society of Training Directors (now the American Society for Training and Development), which held its first national conference in 1945 and continues to be a leading resource and support organization for HRD professionals. Human resource development emerged as "a significant area of human endeavor" during World War II (Nadler, 1970).

\section{The Mid-to-Late 1900s}

Soon after World War II, human resource activities began to be heavily influenced by the behavioral sciences. Researchers Lewin, Benne and Lippett conducted experimental training group processes called "T-groups." The T-group studies were the first laboratory research on group processes, and became the foundation for modern use of lectures with small, unstructured sessions for training (Rothwell \& Sredl, 1992). During the same period, Rensis Likert conducted research on attitudinal surveys to stimulate organizational improvements. These major studies were an attempt to utilize 
the social sciences to understand employee behavior and improve worker motivation, morale, satisfaction and productivity (Rothwell \& Sredl, 1992; Singer, 1990).

In the 1950s, the emphasis of human resource work was in the development of programs in human relations, with a focus of "helping employees to like each other" (Nadler, 1984). Managerial and supervisory training was a priority, and the general assumption was that every supervisor needed human relations training. Courses in sensitivity training and B. F. Skinner's programmed instruction proliferated the training offerings of this time. The government continued its support of human resource activities through the Government Employees Training Act of 1958, which encouraged human resource development for all federal employees (Nadler, 1970).

The government's influence on human resources continued during later decades, but primarily through voluminous legislation rather than through widespread training programs. The rules and regulations imposed on business have affected human resource management requirements and shifted many training efforts toward legislative compliance issues and proactive legal rights education much more than on human relations (Singer, 1990).

Advancing technology has also affected governmental action. The manned space program and the increase in Japanese competition resulted in the widespread use of project groups and task forces. Douglas McGregor's work furthered the behavioral studies which were completed in the previous decade and led to the application of participative management programs in some areas. The economic downturn had a heavy influence on business expenditures, and it once again affected the human resource development offerings in many industries (Nadler, 1984). 
Recently, governmental regulations and industrial relations between management and unions have exerted great influence on the personnel aspects of business (Singer, 1990). Movement from traditional hierarchical control structures has reflected the migration from an industrially-focused economy to a new, information-driven economy, and it promises to have a profound impact on the workplace of the future (Brinkerhoff \& Gill, 1994).

\section{Theory}

Human resource development as a field is the result of convergence of theory and philosophy from several other fields (Rothwell \& Sredl, 1992). The evolution of the human resource development functions have paralleled the evolution of organizational and management theories. According to Kuhn's Structure of Scientific Revolutions, major influences on human resource development have evolved from economics (human capital theory); psychology (industrial and individual psychology); communications (mathematical model and behavior model); education (techniques, humanistic or behavioral); humanities (view of human nature); political science (policy analysis, evaluation research); sociology (culture studies, survey research, statistical analysis); and management (human resources, systems theory, organization behavior, and management science) (in Rothwell \& Sredl, 1992). The roots of human resources as a profession were grounded in the disciplines of human development, behavioral science and business management, and the related theories were explored in some detail for this study. 
$\underline{\text { Scientific Management Theories }}$

Frederick Taylor espoused a set of principles known as scientific management and is regarded as the founder of scientific management theory. Taylor approached management from the standpoint of efficiency, and advocated the analysis of tasks and compensation based upon production criteria (Taylor, 1911). Henry Fayol was another theorist advocating a scientific management approach; his landmark 14 management principles advocated a division of labor, authority, discipline, order and subordination of personal interests (Rothwell \& Sredl, 1992). The scientific, or classical management school resulted in narrowly defined routines, and "the work often became boring, depersonalized, monotonous, dehumanizing and demotivating. Yet, scientific management survived. . long past the point where incontrovertible evidence demonstrated that it was a failure" (Boyett \& Conn, 1991). Changes in the American economy after the early 1900 s challenged the relevancy of the scientific management principles; the workplace organized under scientific management thought was unable to respond to rapid change or to accommodate the increasing complexity of technology and training. The growth of labor's power and societal expectations regarding worker treatment also undermined the desirability of a strict, simplistic scientific management approach (Perrow, 1973).

\section{Human Relations Theories}

Studies by Elton Mayo and F. J. Roethlisberger at the Western Electric plant in Hawthorne, Illinois, provided another serious challenge to the scientific management school of thought. Several experiments conducted at the plant between 1924 and 1932 
formed the basis for human relations theories in management. The human relations theories opposed the scientific management beliefs that money and managerial control were the primary motivators for employees. Mayo and Roethlisberger determined that employees at the plant placed a higher value on social relations with co-workers and were affected as much by perceived management concern as by actual managerial interventions (Rothwell \& Sredl, 1992).

C. I. Barnard claimed a theory for organizations which was responsive to the anti-bureaucracy movement. In The Functions of the Executive, he defined organizations as "a system of cooperative human functions," and advocated embracing a social economy to enhance the organization's relationship to individuals both inside and outside the organization.

\section{$\underline{\text { Motivation Theories }}$}

In the decade of the 1930s, relationships between the individual employee and work groups played a central role in management theories. Many theories during the human relations movement centered on describing the motivation of employees and ways to maximize achievement from workers. Abraham Maslow's needs hierarchy theory provided a foundation for much of the later organization development work. Maslow maintained that human behavior was motivated by a hierarchical set of five variables, and that achievement of one level of needs dominated people's motivations until they were able to strive toward achievement at the next highest level; the basic level of Maslow's hierarchy was the physiological needs, followed by safety (security), social (affiliation), esteem, and finally, self-actualization (Maslow, 1943). 
Frederick Herzberg provided another theory of human motivation which evolved from studies based upon the Hawthorne research. Herzberg's motivation-hygiene theory maintained that a different set of factors contribute to job satisfaction than to job dissatisfaction. Achievement, recognition, responsibility, challenging work and advancement were cited as the five motivators which would enhance morale and performance. Dissatisfiers (or hygiene factors) such as policy and practice, physical working conditions, security, benefits and compensation, could remove dissatisfaction to a point, but did not sufficiently motivate to increase performance (Herzberg, Mausner \& Snyderman, 1959).

\section{$\underline{\text { Managerial Styles }}$}

In 1960, Douglas McGregor's Theory X and Theory Y gave special labels to the two distinctly different management philosophies that had been in existence since the turn of the century (Miner, 1980). Theory X described a traditional managerial theory whereby management is responsible for organizing the system and directing and exerting active intervention to motivate the passive and resistant employees; Theory $\mathrm{X}$ assumes that man is lazy, lacks ambition, dislikes responsibility, prefers to be led, is inherently self-centered, is indifferent to organizational needs, by nature is resistant to change, is gullible, and not very bright. While Theory $\mathrm{Y}$ concurred with Theory $\mathrm{X}$ in the belief that management was responsible for organizing the system, the two theories diverge in all other principles. Theory Y asserted that people have become passive due to poor organizational experiences, but that the motivation and potential are present; managers had "the essential task to arrange organizational conditions and methods of operation so 
that people can achieve their own goals best by directing their efforts toward organizational objectives" (McGregor, 1960). Theory X was aligned with the traditional mode of management, while Theory Y exemplified the human resources model (Miner, 1980).

Rensis Likert expanded upon the Theory X and Theory Y principles in his continuum of management styles from System 1 through System 4. The four systems assessed performance characteristics and organizational variables, including leadership processes, motivational forces, and character of interaction. Management operating from a System 4 perspective has complete confidence and trust in subordinates, provides rewards based on participation, and has high interaction with others (Hersey \& Blanchard, 1977).

Paul Hersey and Kenneth Blanchard plotted the integration between people and production into a matrix in their Situational Leadership Theory; this theory measured relationship behavior against task behavior on a four quadrant matrix to assess the style of the leader and the maturity of the followers. The appropriate leadership style and degree of emphasis on relationship versus task was determined according to the maturity level of the group. The styles ranged from telling to selling, participating and delegating in a counterclockwise reverse bell curve through the quadrants (Hersey \& Blanchard, 1977).

Robert Blake and Jane Mouton provided the Managerial Grid, another theory representing managerial styles in a continuum, through the utilization of a matrix which aligned concern for people on the vertical axis and concern for production on the horizontal axis. The result was a nine by nine matrix with corresponding managerial styles of ways the manager used hierarchy. The Managerial Grid proposed a " 9,9 
approach to organization development," attempting to combine the best levels of interaction between people and production. Black and Mouton asserted that using " 9,9 " managerial concepts was different than traditional organizational interventions, and could "bring an entire organization to a higher level of developing and functioning" (Blake \& Mouton, 1964). The managerial grid concepts were later applied specifically to education in the Academic Administrator Grid, which labeled the 9,9 style as the team administration approach to managerial style and conflict resolution and offered advice to institutional leaders who supervised diverse groups of personnel (Blake, Mouton \& Williams, 1981).

\section{Systems Theory}

Since 1960, more systemic views have dominated management study. Managerial theories previously referenced in this review of literature have primarily addressed specific aspects of the organization and components of leadership. Behavioral scientists observed that organizations were social systems composed of a combination of interacting components; they were described by Daniel Katz and Robert Kahn as either closed or open systems. The latter type of system was dependent entirely upon its surroundings for resources and placed the individual patterns of organizational behavior within the context of the larger social system (Katz \& Kahn, 1978): "Individuals in open systems enact roles, and indeed the organization is a system of roles that regulates member behavior and interpersonal relations. Organizational roles are based on a complex interplay of environmental and organizational factors, role expectations established and sent by others, personal attributes, work group relations and 
interpretations of the role made by the person in it" (Rothwell \& Sredl, 1992).

Modified versions of the systems theory have been attempted in university settings. The Planning, Programming, Budgeting System (PPBS) and the Program Evaluation Review Technique (PERT) were two forms of comprehensive planning which many universities adapted in the 1960s and 1970s (Backoff \& Mitnick, 1981). Critics did not like the complexity of analysis, the failure of systems technologies, and the propensity toward highly centralized administrative functions. Researchers asserted that systems theory should be used beyond the assessment and planning arenas in higher education, and that "the systems approach may yet have many useful applications in the understanding of behavior of universities and in the conduct of university management" (Backoff \& Mitnick, 1981).

The rapid changes in the external environment would suggest that a systemic approach is required by educational institutions to address the calls for reform of the academy: "One such application of systems theory would be the design of an educational system that took into account both the relationship between the internal components and the relationship with the external community components" (Betts, 1992).

Human resources practitioners have in recent times advocated for organizations to ascribe to a greater learning orientation and to develop an organizational structure and process which fosters a learning organization environment (Argyris \& Shon, 1996). Human resources professionals have found themselves increasing the emphasis of their training and offering more in the areas of employee development: "HRD, as a combination of training, career development, and organization development, offers the theoretical integration needed to envision a learning organization" (Marsick \& Watkins, 
1994). The changing competitive environment and the move toward organizational learning will change the roles, skills and tools used by human resource professionals and leaders in the near future.

\section{Roles of Human Resource Development}

There have been a number of attempts to identify the roles, outputs and competencies required by the human resource development professional and by practitioners in the training and development field. In 1976, a study conducted by the Ontario Society for Training and Development identified four primary roles of HRD professionals: (a) instructor, (b) designer, (c) manager, and (d) consultant. This study identified eleven activity areas which were conducted within the four roles: (a) administration, (b) communication, (c) course design, (d) evaluation, (e) group dynamic process, (f) learning theory, (g) human resource planning, (h) person/organization interface, (i) instruction, (j) materials and equipment management, and (k) needs analysis (Rothwell \& Sredl, 1992).

An empirical study of human resource competencies for Fortune 200 companies in the 1990s was conducted through the University of Michigan School of Business. This research project involved 2100 senior human resource officers and nine of the HR officer's work associates in other units of the company or outside of the business. Compilation of the responses provided data to identify six major competencies for human resources: (a) staffing, (b) development, (c) appraisal, (d) rewards, (e) organization planning, and (f) communication (Ulrich, Brockbank \& Yeung, 1989). 
Unprecedented pressures for change were the driving force behind the Society for Human Resource Management's Competency Initiative report in 1990. This report sought to clarify and quantify the competencies for senior-level human resource executives and to identify the role that the senior HR professionals expected human resources to play in meeting the business challenges of the 1990s. The Competency Initiative report identified five competency clusters for senior executives: (a) goal and action management, (b) functional and organizational leadership, (c) influence management, (d) business knowledge, and (e) HR technical proficiency (SHRM Foundation, 1990).

The first major empirical study to identify specific human resource development roles was sponsored by the American Society for Training and Development (ASTD) in 1978. Pinto and Walker surveyed 3,000 HRD professionals and summarized 14 major activities performed in the training and development role: The major functions were: (a) analyzing and diagnosing needs, (b) determining appropriate training approaches, (c) designing and developing programs, (d) developing material sources, (e) managing internal resources, (f) managing external resources, (g) developing and counseling individuals, (h) preparing job/performance-related training, (i) conducting classroom training, (j) developing groups and organizations, (k) conducting research on training, (l) managing working relationships with managers and clients, (m) managing the training and development function, and (n) managing professional self-development (Pinto \& Walker, 1978). 


\section{Models for Excellence}

The American Society for Training and Development sponsored a second comprehensive research study of the training and development field in 1983. Entitled Models for Excellence, the study identified nine broad areas of human resource practice, 34 future forces affecting the training and development field, and 15 key training and development roles. The areas of human resource practice were depicted graphically in a Human Resource Wheel which showed how the nine areas of practice contributed to the five outputs associated with the human resource areas. The areas of practice were identified as follows: (a) training and development, (b) organization development, (c) organization/job design, (d) human resource planning, (e) selection and staffing, (f) personnel research and information systems, $(\mathrm{g})$ compensation/benefits, (h) employee assistance, and (i) union/labor relations. The nine areas of practice contributed to the achievement of the five areas of outputs: (a) quality of work life, (b) productivity, (c) HR satisfaction, (d) HR development, and (e) readiness for change (McLagan \& Bedrick, 1983).

As part of the Models for Excellence study, practitioners in the training and development field identified the following 15 roles which described the major T\&D functions: (a) evaluator, (b) group facilitator, (c) individual development counselor, (d) instructional writer, (e) instructor, (f) manager of training and development, (g) marketer, (h) media specialist, (i) needs analyst, (j) program administrator, (k) program designer, (l) strategist, (m) task analyst, (n) theoretician, and (o) transfer agent (McLagan \& Bedrick, 1983). 


\section{$\underline{\text { Models for HRD Practice }}$}

In 1987, ASTD commissioned a third competencies and standards study to expand on the results of the Models for Excellence research. The ASTD Competencies and Standards Task Force was charged with (1) producing a model for human resource development practice, (2) identifying future forces which would have a significant impact on HRD work, and (3) utilizing experts to update the roles, competencies and outputs associated with human resource development work. Methodology for the study included development of a preliminary model based upon the 1983 research data, augmented with input from HRD experts, organization development experts, and members of local ASTD chapters (McLagan \& Suhadolnik, 1989).

The first phase of the research resulted in the identification of 11 human resource development roles. In the second phase, surveys were returned by 705 experts. Subsequently, an updated model was shared with another group of 1,010 role experts, which resulted in a final modification to the model and delineated the critical future forces predicted for HRD work in the 1990s. The results of the study were published as Models for HRD Practice in 1989. The final report also included an updated comprehensive Human Resource Wheel which linked 11 major areas of human resource practice to five human resource results (see Appendix E). The Human Resource Wheel delineated the relationship of the functional areas to the human resource development process and indicated how all the areas contributed to the achievement of the five results (McLagan \& Suhadolnik, 1989). Permission to reprint the Human Resource Wheel is included in Appendix F. 


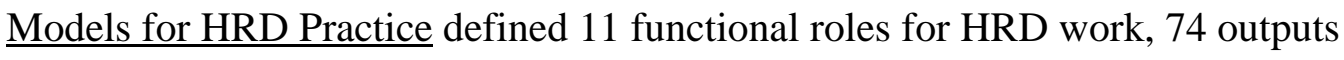
related to the roles, and hundreds of competencies and quality requirements necessary to fully achieve the outputs. The 11 roles identified were defined as follows:

(a) Administrator--"the role of providing coordination and support services for the delivery of HRD programs and services," (b) Evaluator--"the role of identifying the impact of an intervention on individual or organizational effectiveness," (c) HRD Manager--"the role of supporting and leading a group's work and linking that with the total organization," (d) HRD Materials Developer--"the role of producing written or electronically mediated instructional materials," (e) Individual Career Development Advisor--"the role of helping individuals assess personal competencies, values and goals, and to identify, plan and implement development and career actions," (f) Instructor/Facilitator--"the role of presenting information , directing structured learning experiences, and managing group discussions and group process," (g) Marketer--"the role of marketing and contracting for HRD viewpoints, programs and services," (h) Needs Analyst--"the role of identifying ideal and actual performance conditions and determining causes of discrepancies," (i) Organization Change Agent--"the role of influencing and supporting changes in organizational behavior," (j) Program Designer--"the role of preparing objectives, defining content, and selecting activities for a specific intervention," and (k) Researcher--"the role of identifying, developing, or testing new information and translating the information into its implications for improved individual or organizational performance" (McLagan \& Suhadolnik, 1989). 


\section{Trends In Human Resource Development}

There have been a number of studies attempting to predict the major trends in human resource management, and to a lesser degree, the more specialized area of human resource development. The literature was consistent in its prediction that economic, political and sociological factors will have a major influence on human resource development in the next decade. Influences such as technology, changing workforce demographics, increased regulations and governmental legislation, and the globalization of organizations were factors constantly cited as impacting the work of human resource professionals in the future (Gilley \& Eggland, 1989; Kimmerling, 1989; Mirvis, 1993; Pynes, 1997).

The Society for Human Resource Management (SHRM), as part of the 1990 Competency Initiative report, asked senior-level HR professionals to identify issues which would have substantive human resource implications in the future. Over half of the CEOs agreed that three issues would predominate human resource activities in the future: (a) changing/blending organizational culture and values, (b) attracting, retaining, and motivating quality people and (c) training, retraining and developing employees (SHRM Foundation, 1990).

In 1992, the Society for Human Resource Management conducted another study, this one involving 124 top human resource management professionals who worked at America's 350 largest companies. The key areas which were identified in the survey as being the most important and the most difficult issues in the near future were: (a) cost of benefits, (b) recruiting/retaining qualified people, (c) changing workforce demographics, (d) training/retraining, (e) compensation issues, (f) performance/productivity 
management, (g) organizational development and (h) child care (Bergmann, Close \& Will, 1992).

Human resource management in the non-profit sector is not immune to changes affecting the workplace at large. Five emerging issues are identified as being of concern to non-profit HRM administrators: (a) privatization or contracting out of services, (b) violence in the workplace, (c) alternative dispute resolution, (d) computer technology, and (e) technological changes in HRM administration (Pynes, 1997). Additional HRM challenges identified by Pynes as having particular relevance to the non-profit sector include accommodation to a changing workforce, an increase in skill requirements necessary to work in non-profit HRM administration, growing competitiveness in the non-profit sector, and fluid organizational structures (Pynes, 1997).

\section{$\underline{\text { Models for HRD Practice }}$}

A separate component of ASTD's 1989 Models for HRD Practice study was the linkage between future forces and human resource development roles. As part of the second round of role expert questionnaires, respondents provided narrative information as to how they predicted a future force would impact on the functional HRD role which they

were evaluating. The final listing was of the forces which were rated as having the highest potential to impact human resource development work (McLagan \& Suhadolnik, 1989). The 13 future forces as defined by the Models for HRD Practice research were listed in the sequence according to degree of consensus by the experts: 
1. Increased pressure and capacity to measure workforce productivity, performance, cost-effectiveness and efficiency;

2. Increased pressure to demonstrate the value, impact, quality, and practicality of HRD services;

3. Accelerated rate of change and more uncertain business environment;

4. Increased emphasis on customer service and expectation of quality products and services from the workforce;

5. Increased sophistication and variety of tools, technologies, methods, theories and choices in HRD;

6. Increased diversity (demographics, values, experience) at all levels of the workforce;

7. Increased expectations for higher levels of judgment and flexibility in worker contribution (specifically, more creativity, risk taking, adaptation to change, and teamwork);

8. Increased use of systems approaches that integrate HRD systems and technology in the workplace;

9. Business strategies that concentrate more on human resources and require strategic HRD actions:

10. Changed emphasis in organizations from loyalty to merit, accountability, performance, and relevant skills;

11. Globalization of business, increased and expanded international markets, joint ventures, overseas ownerships and competition;

12. Increased need for commitment, meaningful work and participation on the 
job by a larger proportion of the workforce;

13. Increased use of flatter, more flexible organization designs; smaller, self-contained work groups and reduced staff.

(McLagan \& Suhadolnik, 1989).

\section{Human Resources in Higher Education}

Human Resources at colleges and universities evolved just as it did in other organizations. Earlier, both on campus and in business, Personnel was considered a support function, more concerned with the applied administration of hiring than exerting the institution-wide influence on behavior modification as is often the case in the current environment (Mirvis, 1993). Personnel work on college campuses has undergone significant changes since the earliest days when it involved little more than quarterly payroll for the professors and their assistants. The institutions themselves were simple in structure and non-faculty positions were few. Although the complexity of the function grew, until the 1970s the personnel administration function for staff was often absorbed into the work of other administrators who had other responsibilities, while the faculty retained control of personnel administration for their own people (Mackie, 1990).

Prior to 1941, few of the leading universities in the United States had an established staff personnel program, and college personnel administrators did not have a formal inter-campus meeting until 1947 due to insufficient numbers of interested participants. At this initial meeting, the College and University Personnel Association (CUPA) was founded by Donald E. Dickason of the University of Illinois, and membership was open to "all business officers of educational institutions charged with 
personnel functions in their administration" (Harkness, 1965). CUPA now supports a human resource development department, employs 20 staff members, and had a 1997 membership of over 6,400 HR administrators at approximately 1,700 institutions (CUPA Membership Directory and Resource Guide, 1997)

In spite of the growth in CUPA membership, little research has been conducted specifically about human resource development functions at higher education institutions in the United States. Rather than studying the variety of functions within different types of institutions, three studies commissioned by CUPA sought to measure how many fulltime equivalent staff members performed pre-selected human resource functions. These staffing studies were separated only by size of institutions--two-year, mid-sized, and large. The reviews of staffing patterns were descriptive studies and did not lead to recommendations or proposed restructuring of functions (Bouchard, Davidson \& Fortunato, 1992).

Traditionally, educational institutions have not placed a priority on organizational development efforts, in contrast to the attention given to faculty development and professional development for individuals. "By and large, schools need to give more attention to their own organizational development" (Schmuck \& Runkel, 1985). The Academic Administrator Grid (Blake, Mouton \& Williams, 1981) was one of the few organizational development theories specifically developed for education. For the most part, institution leaders and human resource practitioners must adapt other organizational theories for use in academia. Although educational institutions have features which distinguish them from other organizations, the overarching similarities between all organizations allows for the generalizability of organizational theory (Rubenstein \& 
Haberstroh, 1966).

Even though variety of organization type did not preclude generalizing, it was important to the researchers in this review of literature to have some consistency in the size of institutions in the samples taken. Investigators at the University of Aston studied the effect seven variables had on predicting the structure of organizations, and found that size was the best predictor of the structure of activities within organizations (Jackson, Morgan \& Paolillo, 1986). Richard H. Hall indicated that increasing size is related to increasing differentiation, with larger organizations employing more specialists. Administrative control is inversely related to size, and span of control is directly related to size; Hall also found that increased size is related to increased structuring of organizational activities and decreased concentrations of authority (Hall, 1987).

This study was prompted in part by Dr. Beth Triplett's 1997 study, $\underline{\text { Role }}$ Expectations and Predictions of Trends for Human Resource Development at Small, Private Colleges and Universities within the Southern Regional Education Board Area. Triplett found that very few human resource development activities were occurring at small, private colleges within the SREB area, that the time spent on the individual HRD roles varied greatly by role, and that there was a mismatch between what was perceived to be important and what was actually implemented. She also concluded that there were many misconceptions regarding the HRD roles, and that what was often called human resource development was actually human resource management. One of Triplett's recommendations for further study was that a similar study be completed for larger institutions to determine in part whether the lack of HRD efforts at the population studied "is indicative of higher education or an anomaly particular to smaller institutions due to 
their size and lack of personnel specializations" (Triplett, 1997). Although this study is not an exact replication, certain comparisons can logically be made and are cited in the conclusions.

\section{Summary}

The selected review of literature suggests that the field of human resource development has undergone significant change since the turn of the century, and ever increasing change is predicted in the coming decades. This section reviewed the history of human resource development, major theories and managerial styles which have influenced the work of practitioners, and the roles currently performed by those in the field. Also provided was a summary of the key future forces that were identified as likely to have an influence on human resource behaviors.

Industry leaders and theorists have predicted that organizations will respond to changing workforce demographics and growing complexity by placing increased emphasis on organizational learning and employee involvement. This signifies an increasing, changing role for HRD professionals who are charged with responsibilities in the areas of training and development, organization development, and career development. Based on the review of the literature, it is evident that the role of the human resource constituent in organizations continues to evolve. 


\section{Chapter 3}

\section{Research Methods, Procedures, and Demographics}

\section{Population and Sample}

The population for this study consisted of the 26 public, four-year institutions of higher education in the Southern Regional Education Board area that were classified by 1997 SREB-State Data Exchange definitions as SREB I. (see Definitions of Terms in Chapter I and list of institutions, Appendix A). The sample was provided by respondents from 20 of the 26 institutions.

\section{Survey Instrument}

A survey questionnaire was designed, the Human Resource Development (HRD)

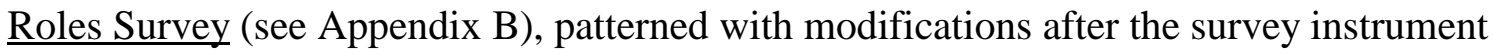
developed by Triplett (1997). The modified questionnaire was mailed to the appropriate officer of each institution with a cover letter (see Appendix C) that included an explanation of the purpose of the study. All 26 chief human resources officers of the institutions were telephoned in advance to assure that the survey instruments would be properly directed and to encourage their support and participation in the study.

Respondents were assured that their participation was voluntary and confidentiality and anonymity would be maintained.

A return rate of $50 \%$ plus one $(n=14)$ was considered an appropriate return rate for this study; as indicated above, the actual return rate was $76.9 \%(\mathrm{n}=20)$. A response from an institution stating that it did not have a person designated to administer 
the human resource development functions was considered a valid return for the purpose of this research; there were no such responses. Approximately four weeks after the survey instrument was mailed, follow-up telephone calls were made to the chief human resource officers whose survey questionnaires had not been returned. In one case, the survey instrument had been lost, and an additional copy was faxed to the participating institution at the respondent's request.

\section{Methodology}

This research project was a descriptive study which gathered questionnaire/survey data from selected universities. All of the four-year, public institutions in the SREB geographic area which were classified by the 1997 SREB-State Data Exchange definitions as SREB I were surveyed. These 26 institutions served as both the population and the sample.

The Human Resource Development (HRD) Roles Survey was utilized to collect data from the HRD administrators at the selected SREB institutions. The instrument was developed specifically for this research purpose as a vehicle to gather demographic data regarding the institution, the human resource development administrator, institutional emphasis upon selected HRD roles, and predictions of trends. The instrument was patterned, with modifications, after a similar instrument developed by Beth Triplett for the research study, Role Expectations and Predictions of Trends for Human Resource Development at Small, Private Colleges and Universities within the Southern Regional

Education Board Area, published at West Virginia University approximately two years 
ago (Triplett, 1997). Specifically, the modifications included the development of rating scales for the "Roles" categories. Questions on the survey regarding the human resource development roles were based on the American Society for Training and Development delineations as reported in Models for HRD Practice (McLagan \& Suhadolnik, 1989).

A return rate of $76.9 \%$ was recorded for this research project $(n=20)$. Findings from the survey regarding individual and institutional demographic data are reported in this chapter.

\section{Analysis of Data}

Standard, nonparametric statistics were used in the initial data analysis for each question: means, frequencies, percentages, emergent category analyses and narrative description. Where appropriate, data were presented in tabular form.

\section{Survey Response}

The population for this study consisted of all 26 public, four-year institutions of higher education in the Southern Regional Education Board (SREB) area that were classified by the 1997 SREB-State Data Exchange definitions as SREB I (see Chapter 1, Definitions of Terms).

A survey questionnaire, the Human Resource Development (HRD) Roles Survey (see Appendix B), patterned with modifications after the survey instrument developed by Triplett (1997), was prepared for distribution to the appropriate officer of each institution with a cover letter (see Appendix C) that included an explanation of the purpose of the study. Chief human resources officers of all 26 institutions were telephoned in advance 
to assure that the survey instruments were properly directed and to encourage timely participation. Respondents were assured that their participation was voluntary and that confidentiality and anonymity would be maintained.

The entire population was surveyed, and follow-up telephone calls were made in a number of instances, both to inquire as to whether the questionnaire had been received, and to clarify some of the information returned; 20 (76.9\%) of the 26 institutions responded with usable instruments (see Appendix D). The Southern Regional Education Board includes the following fifteen states: Alabama, Arkansas, Florida, Georgia, Kentucky, Louisiana, Maryland, Mississippi, North Carolina, Oklahoma, South Carolina, Tennessee, Texas, Virginia, and West Virginia. The sample of 20 universities were representative of 13 of the 15 states surveyed. Survey population and return by state is presented in Table 1.

The Human Resource Development (HRD) Roles Survey requested both institutional and individual demographic data. Respondents were asked whether or not units and/or individuals were assigned to the human resource development role, and all 20 respondents answered affirmatively.

\section{Institutional Demographic Data}

Demographic data relative to the institutions were collected from the respondents. These data included the following: (a) name and state of institution, (b) total headcount student enrollment, (c) total headcount number of employees, and (d) total E \& G (educational and general) expenditures as reported by the institution on the FY98 federal 
IPEDS financial report, which was determined to be an appropriate measurement of annual budget.

The name of the institution was voluntarily disclosed as part of the survey response, and a list of the 20 participating institutions is included in Appendix D. The total student enrollment for the institutions ranged from a low of 14,612 to a high of 42,332 , with a mean of 27,070 ; the statistical mode was within the range of 20,000 to 25,000. The ranges of enrollment are presented in Table 2.

The total number of employees at the sample institutions ranged from a low of 2,750 to a high of 20,277 , with a mean of 7,063 . The mode, however, was within the range of 3,000 to 5,000. The ranges of total employees are presented in Table 3.

Of the 20 respondents, 16 reported their total educational and general expenditures for FY98. The annual budgets ranged from a low of $\$ 232,442,554$ to a high of $\$ 888,633,601$, with a mean of $\$ 446,297,199$. The mode was within the range of $\$ 250$ million to \$350 million. The ranges of annual budgets are presented in Table 4.

The summary profile for the average institutional demographics would be that of a public, four-year university located within the SREB states. The institution would award at least 100 doctoral degrees broadly distributed among at least 10 categories, have an enrollment of approximately 27,000 students, an approximate headcount of 7,000 employees, and an annual budget of approximately \$446 million. 


\section{Table 1}

Survey Population and Return by State

\begin{tabular}{|c|c|c|c|}
\hline State & Population & Return & \% Returned \\
\hline A & 2 & 2 & 100.0 \\
\hline B & 1 & 1 & 100.0 \\
\hline $\mathrm{C}$ & 3 & 2 & 66.7 \\
\hline $\mathrm{D}$ & 2 & 2 & 100.0 \\
\hline $\mathrm{E}$ & 1 & 0 & - \\
\hline $\mathrm{F}$ & 1 & 1 & 100.0 \\
\hline $\mathrm{G}$ & 1 & 1 & 100.0 \\
\hline $\mathrm{H}$ & 1 & 1 & 100.0 \\
\hline I & 2 & 1 & 50.0 \\
\hline $\mathrm{J}$ & 2 & 1 & 50.0 \\
\hline $\mathrm{K}$ & 1 & 0 & - \\
\hline $\mathrm{L}$ & 1 & 1 & 100.0 \\
\hline $\mathrm{M}$ & 5 & 5 & 100.0 \\
\hline $\mathrm{N}$ & 2 & 1 & 50.0 \\
\hline $\mathrm{O}$ & 1 & 1 & 100.0 \\
\hline TOTAL & 26 & 20 & 76.9 \\
\hline
\end{tabular}




\section{Table 2}

\section{$\underline{\text { Total Enrollments (Headcount) }}$}

\begin{tabular}{lcc}
\hline Range & Frequency & Percentage \\
\hline Below 15,000 & 1 & 5 \\
15,000 to 19,999 & 2 & 10 \\
20,000 to 24,999 & 6 & 30 \\
25,000 to 29,999 & 4 & 20 \\
30,000 to 34,999 & 4 & 20 \\
35,000 to 39,999 & 1 & 5 \\
$40,000+$ & 2 & 10 \\
TOTAL & $\mathbf{2 0}$ & $\mathbf{1 0 0}$ \\
\hline
\end{tabular}

Table 3

\section{Total Number of Employees (Headcount)}

Range

Below 3,000

3,000 to 4,999

5,000 to 6,999

7,000 to 8,999

9,000 to 10,999

$11,000+$

TOTAL

\section{Frequency}

1

7

5

1

4

2

20

\section{Percentage}

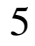

35

25

5

20

10

100 
Table 4

\section{Annual Budget (FY98 Educational and General Expenditures)}

Range (\$Millions)

Below \$250

$\$ 250$ to $\$ 349.9$

$\$ 350$ to $\$ 449.9$

$\$ 450$ to $\$ 549.9$

$\$ 550$ to $\$ 649.9$

$\$ 650$ to $\$ 749.9$

$\$ 750+$

TOTAL

Frequency

1

8

1

1

1

2

2

16

\section{Percentage}

6.25

50.0

6.25

6.25

6.25

12.5

12.5

100.0

\section{Individual Demographic Data}

A number of questions were asked on the Human Resource Development (HRD)

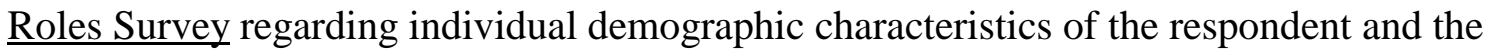
HRD position that he/she held. Individual demographics were collected on: (a) job title, (b) number of years in the current position, (c) number of years at the institution, (d) number of years in any human resource development role, (e) gender, (f) highest educational level, and (g) degree major. Positional information was collected regarding (a) job title of the person to whom the HRD person reported, (b) whether the position was full-time or part-time, (c) the percentage of responsibilities assigned to the HRD role, and (d) other responsibilities if the position was not exclusively assigned to HRD functions. 
With minor variation, there were a total of 10 different titles assigned to the person responsible for human resource development at the 20 responding institutions. The most frequent title was Director of Personnel (or Personnel Services), and the next most common titles were Director of Human Resources, Assistant Vice President for Human Resources, and Assistant or Associate Vice Chancellor for Human Resources. Those four titles accounted for $65 \%$ of the reported titles. The remaining titles included Executive Director, Director, Assistant Director, Manager, and Coordinator. The data in Table 5 present a summary of title variations and frequencies.

Respondents were also asked to report (a) the number of years served in their current position, (b) the number of years at their present institution, and (c) the number of years in any human resource development role. The data presented in Table 6 indicate that $55 \%$ of the respondents had been in their position for 3 years or less. The percentage of respondents serving their present institution for the same 0 - 3 years time interval was only $35 \%$, and only $5 \%$ reported 3 years or less service in any HRD role. The table shows that more of the respondents had been in their current role for fewer years, but that the reverse is true when reviewing the total number of years in any HRD role.

The respondents' gender was also reported. Of the 20 respondents, nine were male and eleven were female. These data are presented in Table 7.

Information regarding the highest educational level attained by respondents was collected as part of the Human Resource Development (HRD) Roles Survey. The largest group of respondents had received Master's degrees (45\%), with other responses ranging from Associate's degree to Doctorate. The educational levels attained by the respondents are summarized in Table 8. 


\section{Table 5}

Job Title of Person in Human Resource Development Role

\section{Title}

Associate or Assistant Vice Chancellor, Human Resources

Assistant Vice President, Human Resources

Executive Director, Human Resources Mgt.

Director, Human Resources

Director, Personnel (Personnel Services)

Director, Training \& Development

(Organization \& Employee Development)

Assistant Director, Human Resources

Assistant Director, Employee Relations \&

Development

Manager, Training

Coordinator, Human Resources

TOTAL
Frequency

3

3

15

5

15

20

10

2

1

5

1

5

5

5

20 


\section{Table 6}

Distribution of Number of Years in Human Resource Development Role

\begin{tabular}{lccc}
\hline Yrs. Employment & $\begin{array}{c}\text { In Current } \\
\text { Position }\end{array}$ & At Institution & $\begin{array}{c}\text { In Any } \\
\text { HRD Role }\end{array}$ \\
\hline $0-3$ Years & $11(55 \%)$ & $7(35 \%)$ & $1(5 \%)$ \\
$4-7$ Years & $2(10 \%)$ & $2(10 \%)$ & $0(0 \%)$ \\
$8-12$ Years & $5(25 \%)$ & $2(10 \%)$ & $4(20 \%)$ \\
$13+$ Years & $2(10 \%)$ & $9(45 \%)$ & $15(75 \%)$ \\
TOTAL & $\mathbf{2 0 ( 1 0 0 \% )}$ & $\mathbf{2 0 ( \mathbf { 1 0 0 \% } )}$ & $\mathbf{2 0}(\mathbf{1 0 0 \%})$ \\
\hline
\end{tabular}

Table 7

Gender of Respondents

\begin{tabular}{lcc}
\hline Gender & Frequency & Percentage \\
Male & 9 & 45 \\
Female & 11 & 55 \\
TOTAL & $\mathbf{2 0}$ & $\mathbf{1 0 0}$ \\
\hline
\end{tabular}




\section{Table 8}

\section{Highest Educational Level Attained By Respondents}

\begin{tabular}{lcc}
\hline Educational Level & Frequency & Percentage \\
\hline Associate's & 1 & 5 \\
Bachelor's & 5 & 25 \\
Master's & 9 & 45 \\
Doctorate & 5 & 25 \\
TOTAL & $\mathbf{2 0}$ & $\mathbf{1 0 0}$ \\
\hline
\end{tabular}

In addition to highest educational level attained, respondents were also asked to indicate their degree major. Business Administration or a business-related field were the most frequent majors (45\%); 25\% cited Education, and 15\% the social sciences. Among those reporting a business major, only one indicated Human Resource Management, and none cited Human Resource Development. Two respondents did not indicate a major field. The summary of majors by field is reported in Table 9 .

Just as reflected in the educational background of the respondents, a predominance of business was also reflected in the job titles of the persons to whom the human resource development administrators reported. Over half of the respondents (65\%) assigned to the HRD role reported to a vice chancellor, vice president, or associate vice president of finance and/or administration; only one reported directly to a chancellor. Thirty percent had been delegated the HRD responsibility by a human resources officer, and reported directly to an associate/assistant vice president, director, or associate/assistant director of human resources. The distribution of supervisor titles is presented in Table 10. 


\section{Table 9}

\section{Major in Highest Educational Level Attained by Respondents}

\begin{tabular}{lcc}
\hline Major Field & Frequency & Percentage \\
\hline Business Administration & 4 & 20 \\
Other Business Fields & 5 & 25 \\
Education & 5 & 25 \\
Social Sciences & 3 & 15 \\
Arts \& Sciences & 1 & 5 \\
Not Reported & 2 & 10 \\
TOTAL & $\mathbf{2 0}$ & $\mathbf{1 0 0}$ \\
\hline
\end{tabular}

The last set of descriptors for individual demographics solicited on the Human Resource Development (HRD) Roles Survey related to the percentage of time assigned to HRD roles. All 20 of the respondents reported a full-time assignment. However, $65 \%$ of the respondents indicated that less than half of their workload was assigned to human resource development responsibilities; only $30 \%$ were assigned human resource development for $100 \%$ of their responsibilities. The frequency distribution of HRD time allocations is presented in Table 11. 


\section{Table 10}

\section{Job Title of Person To Whom Human Resource Development Reports}

\section{Title of Immediate Superior}

Chancellor

Executive VP, Chief Business Officer

Vice Chancellor, Administration and Finance

VP, Administration and Finance (and Human Resources)

Associate VP, Administrative Affairs

Associate/Assistant VP, Human Resources

Director, Human Resources Management

Associate Director, Human Resources

Assistant Director, Employment and Training

TOTAL

Frequency

1

1

3

7

2

3

1

1

1

20

\section{Percentage}

5

5

15

35

10

15

5

5

5

100 


\section{Table 11}

\section{Percent of Responsibilities Assigned To Human Resource Development Role}

\section{HRD Responsibilities}

$1-25 \%$

$26-50 \%$

$51-75 \%$

$76-99 \%$

$100 \%$

TOTAL

Frequency

8

5

0

1

6

20
Percentage

40

25

0

5

30

100

Of the 14 respondents whose assignments were less than $100 \%$ devoted to human resource development roles, $64 \%$ were also responsible for the other traditional human resource management functions--employment, compensation, employee benefits, and employee relations; three other respondents had those traditional functions plus either payroll or information systems, and two respondents had limited functions within those already mentioned. These data are reported in Table 12. 


\section{Table 12}

\section{$\underline{\text { Responsibilities in Addition to Human Resource Development }}$}

Other Responsibilities Frequency

9

Employment, Compensation, Benefits, Employee Relations

Employment, Compensation, Benefits, Employee Relations, plus Payroll

Employment, Compensation, Benefits, $\quad 1$ Employee Relations, plus Information Systems

Employment, Compensation, 1 Employee Relations, plus Information Systems

Information Systems

1

TOTAL
Percentage (approx.)

64.2

14.2

7.2

100.0 


\section{Chapter 4}

\section{Results of Survey}

This chapter provides a description and analysis of the data collected in this study of roles and trends for human resource development. The purpose of the study was to identify role expectations, reporting hierarchy, years in role and trends in human resource development as reported by the person responsible for human resource development in large public universities within the Southern Regional Education Board (SREB) area. This chapter is divided into the following sections: (a) analysis of HRD roles, (b) analysis of HRD trends, (c) major findings, (d) ancillary findings, and (e) a chapter summary.

\section{Analysis of HRD Roles}

The first three sections of the Human Resource Development (HRD) Roles Survey solicited responses regarding demographic characteristics of the institution, the respondent and the respondent's position. The last section of the instrument was utilized to collect data regarding institutional emphasis placed upon the 11 human resource development roles (as defined by the American Society for Training and Development) and expectations and predictions of trends for selected HRD roles.

The survey instrument was patterned, with modifications, after a similar instrument developed by Beth Triplett in 1997 for the doctoral dissertation Role Expectations and Predictions of Trends for Human Resource Development at Small, Private Colleges and Universities within the Southern Regional Education Board Area, submitted that year at West Virginia University. The 11 selected roles were identified through a comprehensive study 
commissioned by the American Society for Training and Development to identify and define the key functions of human resource development work. The outcome of this study was presented in the Models for HRD Practice report and was used as the basis for Triplett's survey instrument (McLagan \& Suhadolnik, 1989). The 11 functions which define the areas of HRD work were: (a) Administrator, (b) Evaluator, (c) HRD Manager, (d) HRD Materials Developer, (e) Individual Career Development Advisor, (f) Instructor/Facilitator, (g) Marketer, (h) Needs Analyst, (i) Organization Change Agent, (j) Program Designer, and (k) Researcher (McLagan \& Suhadolnik, 1989).

In order to determine the general extent to which each of the 11 roles was currently expected of them, respondents were asked to specify, on a scale of 1 to 5 , the emphasis placed on the role by the institution $(1=$ negligible, $2=$ below average, $3=$ average, $4=$ above average, $5=$ strong). The Administrator role received the greatest number of level 5 responses and was the function receiving the highest average emphasis (4.25) as well. The HRD Manager role was cited with the second greatest emphasis, averaging a 4.05 level. Two of the roles fell below the 3.00 (average) level. The Individual Career Development Adviser was the least emphasized role, with the greatest number of level 1 responses ("negligible") and the lowest average emphasis (2.65) as reported by all respondents; the Researcher role followed closely at an average emphasis of 2.85. The summary of institutional emphasis placed on HRD roles, with roles listed in order of emphasis, is presented in Table 13.

Perceptions varied somewhat regarding the institutional emphasis placed on selected HRD roles according to the length of time the respondent had spent in human 
resource development work. In the earlier analysis of individual demographic data (Table 6), years of employment were categorized in time frames utilized in Triplett's study of small colleges and universities within the SREB; this was for the purpose of comparisons in the conclusions and recommendations of this study. However, the respondents in this study involved so few with less than 8 years in HRD roles that the time frames used in Table 6 appeared to be no significant test for a role emphasis/ length of time in HRD comparison. Therefore, the emergent time-frame categories used are only two: 0 - 12 years, and $13+$ years.

Respondents with the fewest number of years in the field perceived heaviest institutional emphasis upon the Instructor/Facilitator role, whereas those with longer service in the field perceived heaviest emphasis on the Administrator role. Emphasis on the Program Designer and Marketer roles was also noticeably higher for the less experienced than for those with longer years in service. Those with fewer years in service reported less emphasis upon the Researcher, Evaluator, Needs Analyst, and Organization Change Agent roles than did those with longer years in the field. Although the longer-HRD-service respondents reported the lowest average emphasis upon the Individual Career Development Advisor role, those with fewer years in HRD did not, citing the Researcher and Evaluator roles as least emphasized. The institutional emphasis placed upon HRD roles by respondent's years in HRD, with roles listed in order of emphasis, are reported in Tables 14 and 15. 
Table 13

Summary of Institutional Emphasis Placed Upon HRD Roles

Emphasis Levels: $\quad \begin{aligned} & 1=\text { Negligible } \\ & 2=\text { Below Average } \\ & 3=\text { Average } \\ & 4=\text { Above Average } \\ & 5=\text { Strong }\end{aligned}$

\begin{tabular}{|c|c|c|c|c|c|c|}
\hline \multirow[b]{2}{*}{ HRD Roles } & \multicolumn{5}{|c|}{ Frequency of Emphasis Level } & \multirow[b]{2}{*}{ Average Emphasis } \\
\hline & 1 & 2 & 3 & 4 & 5 & \\
\hline Administrator & 0 & 0 & 5 & 5 & 10 & 4.25 \\
\hline HRD Manager & 0 & 0 & 5 & 9 & 6 & 4.05 \\
\hline Instructor/Facilitator & 0 & 1 & 7 & 8 & 4 & 3.75 \\
\hline Program Designer & 0 & 1 & 8 & 8 & 3 & 3.65 \\
\hline Marketer & 1 & 2 & 5 & 7 & 5 & 3.65 \\
\hline HRD Materials Developer & 1 & 1 & 10 & 5 & 3 & 3.40 \\
\hline Organization Change Agent & 1 & 5 & 3 & 8 & 3 & 3.35 \\
\hline Needs Analyst & 2 & 4 & 5 & 7 & 2 & 3.15 \\
\hline Evaluator & 2 & 5 & 6 & 4 & 3 & 3.05 \\
\hline Researcher & 2 & 6 & 7 & 3 & 2 & 2.85 \\
\hline \multicolumn{7}{|l|}{ Individual Career } \\
\hline Development Advisor & 5 & 4 & 6 & 3 & 2 & 2.65 \\
\hline
\end{tabular}


Table 14

Institutional Emphasis Upon HRD Roles By Respondent's Years in HRD

$\underline{0 \text { - } 12 \text { Years }}$

$$
\text { Emphasis Levels: } \quad \begin{aligned}
& 1=\text { Negligible } \\
& 2=\text { Below Average } \\
& 3=\text { Average } \\
& 4=\text { Above Average } \\
& 5=\text { Strong }
\end{aligned}
$$

\begin{tabular}{lllllll}
\hline & \multicolumn{7}{c}{ Frequency of Emphasis Level } & \\
HRD Roles & $\mathbf{1}$ & $\mathbf{2}$ & $\mathbf{3}$ & $\mathbf{4}$ & $\mathbf{5}$ & Average Emphasis \\
Instructor/Facilitator & 0 & 0 & 0 & 3 & 2 & 4.40 \\
HRD Manager & 0 & 0 & 0 & 4 & 1 & 4.20 \\
Program Designer & 0 & 0 & 0 & 4 & 1 & 4.20 \\
Administrator & 0 & 0 & 1 & 2 & 2 & 4.20 \\
Marketer & 1 & 0 & 0 & 1 & 3 & 4.00 \\
HRD Materials Developer & 0 & 0 & 3 & 1 & 1 & 3.60 \\
Organization Change Agent & 0 & 2 & 1 & 2 & 0 & 3.00 \\
Needs Analyst & 0 & 2 & 2 & 1 & 0 & 2.80 \\
Individual Career & & & & & & \\
$\quad$ Development Advisor & 2 & 0 & 1 & 1 & 1 & 2.80 \\
Evaluator & 0 & 2 & 3 & 0 & 0 & 2.60 \\
Researcher & 1 & 2 & 2 & 0 & 0 & 2.20 \\
\hline
\end{tabular}


Table 15

Institutional Emphasis Upon HRD Roles By Respondent's Years in HRD

\section{$\underline{13+\text { Years }}$}

$$
\text { Emphasis Levels: } \quad \begin{aligned}
& 1=\text { Negligible } \\
& 2=\text { Below Average } \\
& 3=\text { Average } \\
& 4=\text { Above Average } \\
& 5=\text { Strong }
\end{aligned}
$$

\begin{tabular}{lllllll}
\hline & \multicolumn{7}{c}{ Frequency of Emphasis Level } & \\
HRD Roles & $\mathbf{1}$ & $\mathbf{2}$ & $\mathbf{3}$ & $\mathbf{4}$ & $\mathbf{5}$ & Average Emphasis \\
Administrator & 0 & 0 & 4 & 3 & 8 & 4.27 \\
HRD Manager & 0 & 0 & 5 & 5 & 5 & 4.00 \\
Instructor/Facilitator & 0 & 1 & 7 & 5 & 2 & 3.53 \\
Marketer & 0 & 2 & 5 & 6 & 2 & 3.53 \\
Organization Change Agent & 1 & 3 & 2 & 6 & 3 & 3.47 \\
Program Designer & 0 & 1 & 8 & 4 & 2 & 3.47 \\
HRD Materials Developer & 1 & 1 & 7 & 4 & 2 & 3.33 \\
Needs Analyst & 2 & 2 & 3 & 6 & 2 & 3.27 \\
Evaluator & 2 & 3 & 3 & 4 & 3 & 3.20 \\
Researcher & 1 & 4 & 5 & 3 & 2 & 3.07 \\
Individual Career & & & & & & \\
$\quad$ Development Advisor & 3 & 4 & 5 & 2 & 1 & 2.60 \\
\hline
\end{tabular}




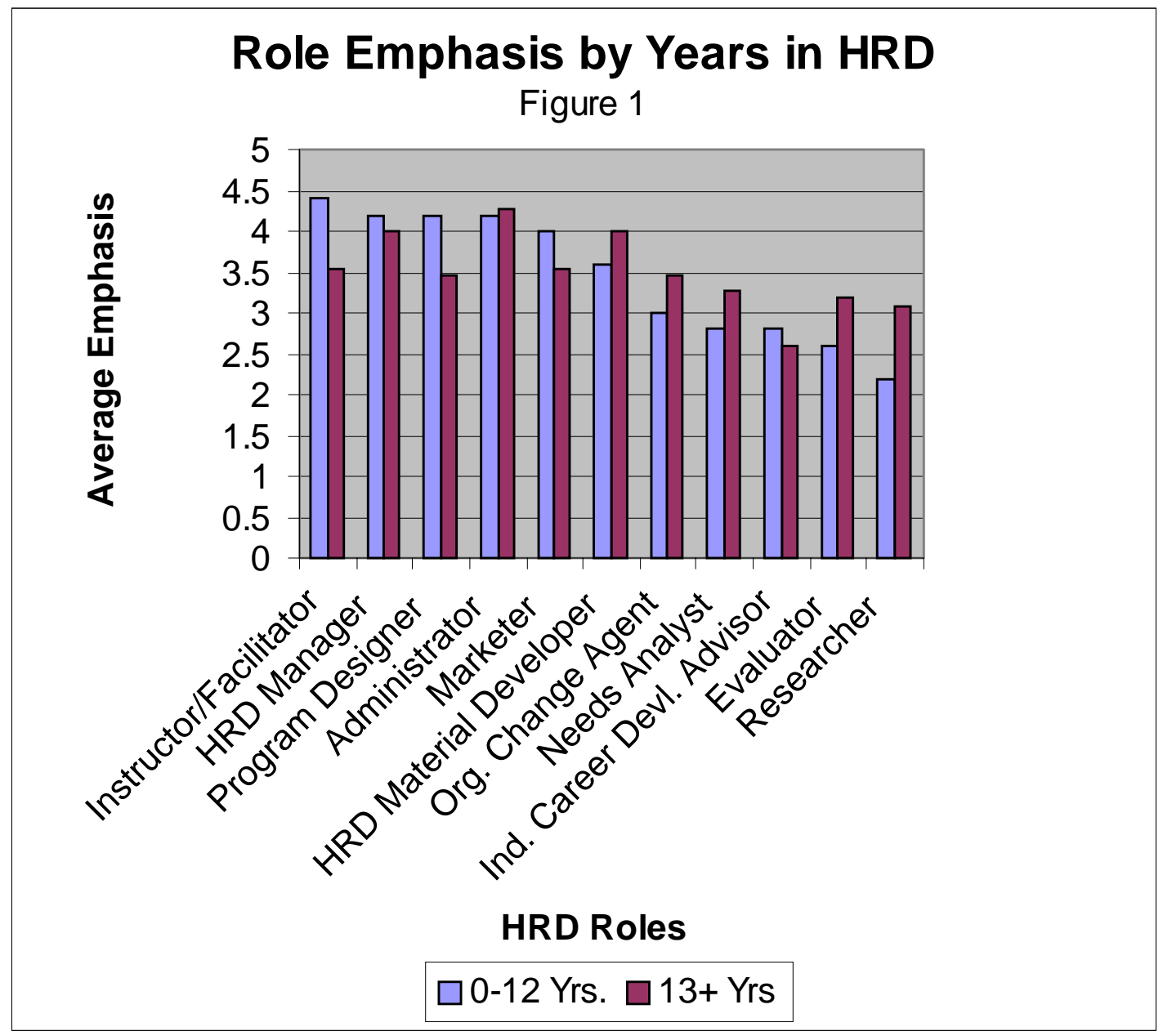


Perceptions also varied regarding the institutional emphasis placed upon selected HRD roles according to the percent of respondent's responsibilities assigned to human resource development. Respondents were asked to categorize the percent of their total responsibilities assigned to HRD roles as follows: $1-25 \%, 26-50 \%, 51-75 \%, 76-99 \%$ and $100 \%$ (see Table 11). Since there were no respondents reporting $51-75 \%$, the emergent percentage categories used in Tables 16 and 17 are 1 - 50\% (less than a majority of the workload) and $76-100 \%$ (an appreciable majority of the workload). Of the 20 respondents, $13(65 \%)$ reported less than a majority of their work assignments in HRD roles, and there was minor variation between this group's perceived institutional emphasis upon the individual HRD roles and that reported by the respondents in total (Table 13). However, those respondents whose HRD responsibilities were a clear majority of their workload perceived a heavier institutional emphasis on the Marketer role--on an equal plane, in fact, with the Administrator role as highest average emphasis of the 11 roles. Those with the largest percentage of their assignments devoted to HRD also ranked the role of Researcher relatively higher than did the other group. These data, with roles listed in order of emphasis, are presented in Tables 16 and 17. 
Table 16

Institutional Emphasis Upon HRD Roles By Percent of Respondent's Responsibilities Assigned to HRD

$\underline{1-50 \%}$

$$
\text { Emphasis Levels: } \quad \begin{aligned}
& 1=\text { Negligible } \\
& 2=\text { Below Average } \\
& 3=\text { Average } \\
& 4=\text { Above Average } \\
& 5=\text { Strong }
\end{aligned}
$$

\begin{tabular}{|c|c|c|c|c|c|c|}
\hline \multirow[b]{2}{*}{$\underline{\text { HRD Roles }}$} & \multicolumn{5}{|c|}{ Frequency of Emphasis Level } & \multirow[b]{2}{*}{ Average Emphasis } \\
\hline & $\underline{\mathbf{1}}$ & $\underline{\mathbf{2}}$ & $\underline{\mathbf{3}}$ & $\underline{4}$ & $\underline{5}$ & \\
\hline Administrator & 0 & 0 & 4 & 3 & 6 & 4.15 \\
\hline HRD Manager & 0 & 0 & 4 & 5 & 4 & 4.00 \\
\hline Instructor/Facilitator & 0 & 1 & 5 & 5 & 2 & 3.62 \\
\hline Program Designer & 0 & 1 & 5 & 6 & 1 & 3.54 \\
\hline Organization Change Agent & 1 & 2 & 3 & 5 & 2 & 3.38 \\
\hline Marketer & 1 & 2 & 4 & 5 & 1 & 3.23 \\
\hline HRD Materials Developer & 1 & 1 & 6 & 4 & 1 & 3.23 \\
\hline Needs Analyst & 1 & 3 & 2 & 6 & 1 & 3.23 \\
\hline Evaluator & 2 & 3 & 3 & 3 & 2 & 3.00 \\
\hline Researcher & 2 & 5 & 3 & 2 & 1 & 2.62 \\
\hline \multicolumn{7}{|l|}{ Individual Career } \\
\hline Development Advisor & 3 & 3 & 4 & 2 & 1 & 2.62 \\
\hline
\end{tabular}


Table 17

Institutional Emphasis Upon HRD Roles By Percent of Respondent's Responsibilities Assigned to HRD

$76-100 \% *$

$$
\begin{array}{ll}
\text { Emphasis Levels: } & 1=\text { Negligible } \\
& 2=\text { Below Average } \\
& =\text { Average } \\
4 & =\text { Above Average } \\
5 & =\text { Strong }
\end{array}
$$

\begin{tabular}{lllllll}
\hline \multirow{2}{*}{ HRD Roles } & \multicolumn{6}{c}{ Frequency of Emphasis Level } \\
Administrator & $\underline{\mathbf{1}}$ & $\underline{\mathbf{2}}$ & $\underline{\mathbf{3}}$ & $\underline{\mathbf{5}}$ & $\underline{\mathbf{5}}$ & Average Emphasis \\
Marketer & 0 & 0 & 1 & 2 & 4 & 4.43 \\
HRD Manager & 0 & 0 & 1 & 2 & 4 & 4.43 \\
Instructor/Facilitator & 0 & 0 & 2 & 3 & 2 & 4.14 \\
Program Designer & 0 & 0 & 3 & 2 & 2 & 3.00 \\
HRD Materials Developer & 0 & 0 & 4 & 1 & 2 & 3.71 \\
Organization Change Agent & 0 & 3 & 0 & 3 & 1 & 3.29 \\
Researcher & 0 & 1 & 4 & 1 & 1 & 3.29 \\
Evaluator & 0 & 2 & 3 & 1 & 1 & 3.14 \\
Needs Analyst & 1 & 1 & 3 & 1 & 1 & 3.00 \\
Individual Career & & & & & & \\
$\quad$ Development Advisor & 2 & 1 & 2 & 1 & 1 & 2.71 \\
& & & & &
\end{tabular}

*Note: There were no respondents who indicated $51-75 \%$ of responsibilities assigned to human resource development roles. 
Role Emphasis By Percent Assigned to HRD

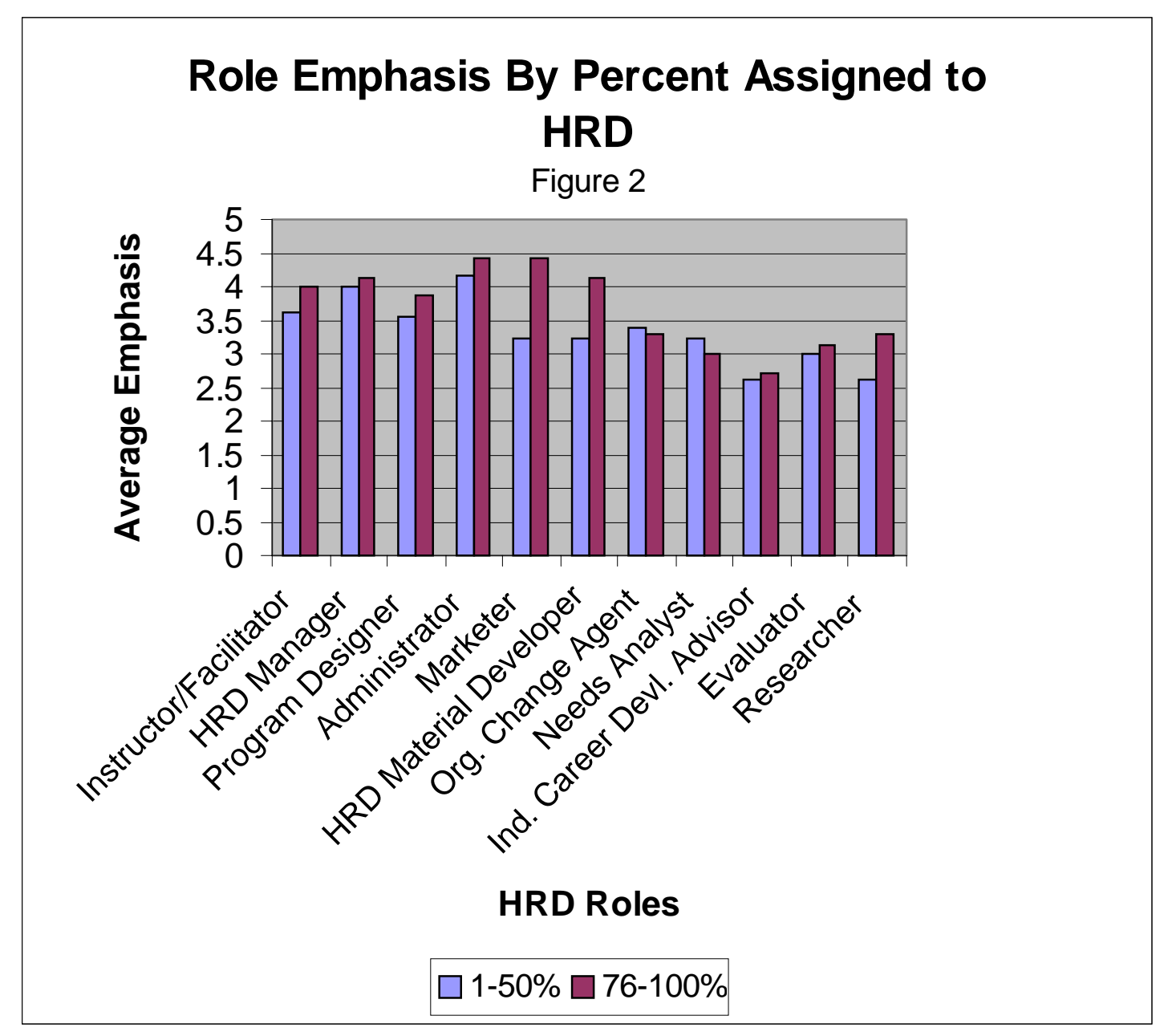




\section{Analysis of HRD Trends}

In addition to questions about institutional emphasis placed upon the human resource development roles, respondents were also asked to provide personal expectations of whether each of the 11 human resource development roles would increase in emphasis, decrease in emphasis, or remain about the same on their campus by the year 2010. One of the respondents chose not to answer the question.

Of 19 respondents predicting changes in emphasis, only one predicted a decrease in any HRD role; the remaining 18 predicted either an increase in emphasis or no change in emphasis for all $11 \mathrm{HRD}$ roles at their institution. The HRD roles predicted most often for expected increase in emphasis were Organization Change Agent and Evaluator, while the role least frequently predicted for increased emphasis was Administrator. These data, with roles listed in order of expected increase in emphasis, are presented in Table 18.

In addition to providing structured predictions regarding expected changes in emphasis upon the $11 \mathrm{HRD}$ roles, respondents were afforded the opportunity to respond to an open-ended question to list any changes which they expected to occur in human resource development at their institutions by the year 2010. Of the 20 respondents, 18 $(90 \%)$ provided data in this format. The majority of the responses indicated anticipated growth in overall human resources responsibilities, although none mentioned any anticipated growth in HR staffing to accommodate the increased needs. The majority of respondents also indicated an anticipated increase in focus and growth of training and development programs for all levels of the organization. An emergent category analysis was conducted to summarize the key categories of change predicted for human resource 
development in the next decade. These data are reported in Table 19. A complete listing of all responses to the question is reported in Appendix G.

\section{Table 18}

\section{Frequency Distribution of}

Expectation for Increase/Decrease in Emphasis Placed Upon HRD Roles

By the Year 2010

\begin{tabular}{|c|c|c|c|}
\hline HRD Roles & Decrease & No Change & Increase \\
\hline Organization Change Agent & 0 & 2 & 17 \\
\hline Evaluator & 0 & 2 & 17 \\
\hline Needs Analyst & 0 & 3 & 16 \\
\hline Researcher & 0 & 6 & 13 \\
\hline Program Designer & 1 & 5 & 13 \\
\hline Marketer & 0 & 7 & 12 \\
\hline \multicolumn{4}{|l|}{ Individual Career } \\
\hline Development Advisor & 1 & 6 & 12 \\
\hline Instructor/Facilitator & 0 & 8 & 11 \\
\hline HRD Materials Developer & 1 & 7 & 11 \\
\hline HRD Manager & 0 & 10 & 9 \\
\hline Administrator & 0 & 11 & 8 \\
\hline
\end{tabular}


Table 19

Emergent Category Analysis for Predicted Changes in Human Resource Development

Trends

Growth in overall human resources responsibilities

Increase in training and development programs

More involvement in strategic planning

Increase in organization and workforce change

Continued advancing technology and resulting new concepts
Frequency

14

13

8

7

5

Note: Multiple responses were possible. 


\section{Major Findings}

The Human Resource Development (HRD) Roles Survey was designed to provide information to address five research questions. Utilizing both qualitative and quantitative data received from the respondents, the following interpretations were made regarding the responses to the research inquiries. Findings from the study are presented following the research question to which the data pertain.

\section{Question 1}

\section{What is the reporting hierarchy for the person(s) responsible for human resource development functions?}

The survey instrument was sent to the chief human resources officer of each institution. In the majority of cases, this was the individual assigned the responsibility for human resources development. In some cases, however, the survey was then given by the initial recipient to a subordinate who, at that institution, was delegated the full responsibility for human resources development roles as defined. As indicated in Table 10 , over half $(65 \%)$ of the respondents assigned to the human resource development role reported directly to a vice chancellor, vice president, or associate vice president of finance and/or administration. Thirty percent were delegated the HRD responsibility by a human resources officer and reported directly to an associate or assistant vice president, director, or associate/assistant director of human resources. Only one (5\%) of the respondents reported 
directly to a chancellor (systems officer equivalent to university president). The organizational level (emergent categories) to which the person responsible for human resource development reports at the respondents' institutions are summarized in Table 20.

Table 20

Organizational Level to which Human Resource Development Reports

\section{Organizational Level}

First Level

(Chancellor or President)

Second Level

(Executive Vice President,

Vice Chancellor, Vice President)

Third Level

(Associate/Assistant Vice President,

Director)

Fourth Level

(Associate/Assistant Director)

TOTAL

\section{Frequency}

1

11

55

6

30

2

10

20

5

10

\section{Percentage}

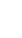

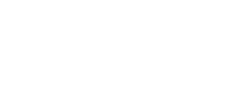

\section{Question 2}

What functions are expected to be performed by the human resource development $\operatorname{person}(\mathbf{s}) ?$

As indicated in Table 11, 14 of the 20 respondents (70\%) had assignments that 
were less than $100 \%$ devoted to human resource development; most $(65 \%)$ had at least half of their responsibilities in areas other than HRD. Table 12 showed that, of those 14 respondents, $13(93 \%)$ had major responsibilities in at least three of the other four traditional human resource management (personnel) functions, and could therefore be described as holding a position with an overall human resource management responsibility rather than one with a primary focus upon human resource development. Seven of the 20 respondents (35\%) held positions the majority of which were devoted to HRD, and six of those performed HRD roles $100 \%$ of the time.

It can be assumed that a respondent's report of "negligible" institutional emphasis upon a specific HRD role indicates a function that is not expected to be performed, and conversely, that a report of any other level of institutional emphasis indicates that the function is expected to be performed, at least to some degree. As presented in Table 16, only four of the $11 \mathrm{HRD}$ roles were expected to be performed to some degree by all 13 of the respondents whose responsibilities were no more than $50 \%$ human resource development. Those roles were Administrator, HRD Manager, Instructor/Facilitator, and Program Designer, and those roles also had the highest average institutional emphasis for those respondents. Table 17 indicates that nine of the $11 \mathrm{HRD}$ roles were expected to be performed to some degree by all seven of the respondents whose responsibilities assigned to human resource development ranged from $76 \%$ to $100 \%$. 


\section{Question 3}

\section{To what extent do the institutions place emphasis upon specific human resource}

development functions/roles?

As indicated in Table 13, Administrator, HRD Manager, and Instructor/Facilitator had the greatest average emphasis of the 11 identified roles at the responding institutions, and those three roles, on average, remained the most emphasized regardless of the respondents' number of years in HRD (Tables 14 and 15) or their percent of responsibilities assigned to HRD (Tables 16 and 17). There were two notable variances: (1) the Program Designer role received greater emphasis at those institutions where the respondent had fewer years in HRD, and (2) the Marketer role received greater emphasis at those institutions where the majority of the respondent's responsibilities were assigned to HRD.

The least emphasized HRD roles at the respondents' institutions were Individual Career Development Advisor, Researcher, Evaluator, and Needs Analyst (Table 13); even though the order of emphasis changed slightly, those four roles had the least emphasis of the 11 identified HRD roles regardless of the respondents' number of years in HRD (Tables 14 and 15) or their percent of responsibilities assigned to HRD (Tables 16 and 17).

To determine whether organizational level to which HRD reports appeared to be a factor in institutional emphasis upon HRD roles, two emergent categories of organization level were created from Table 20: First and Second Level (Vice President or 
above), and Third and Fourth Level (Associate/Assistant Vice President or below). At

those 12 institutions where HRD reported to the first or second organizational level, the average relative emphasis of HRD roles remained basically the same as summarized for all respondents in Table 13. At the eight institutions where HRD reported to the third or fourth organizational level, there was a noticeable increase in the average emphasis placed upon the roles of Program Designer, Marketer, and HRD Materials Developer-those roles given emphasis equal to that of Instructor/Facilitator (the Administrator and HRD Manager roles still had greatest average emphasis); relative emphasis upon the Needs Analyst role also increased slightly, but the other "least emphasis roles" cited above retained the least average emphasis for this group as well. The average emphasis upon the Organization Change Agent role was noticeably higher where HRD reported to the first or second organizational level. Data for institutional emphasis placed upon HRD roles by organization level to which HRD reports, arranged in order of average emphasis, are summarized in Tables 21 and 22. 
Table 21

Institutional Emphasis Placed Upon HRD Roles By Organization Level

To Which HRD Reports

First and Second Level (Chancellor or President, Executive Vice President, Vice Chancellor, Vice President)

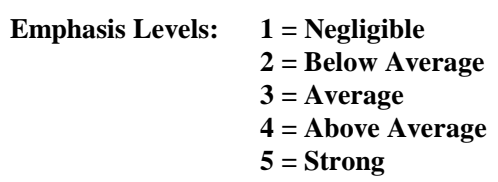

\begin{tabular}{|c|c|c|c|c|c|c|}
\hline & \multicolumn{5}{|c|}{ Frequency of Emphasis Level } & \multirow[b]{2}{*}{$\underline{\text { Average Emphasis }}$} \\
\hline HRD Roles & $\underline{1}$ & $\underline{\mathbf{2}}$ & $\underline{\mathbf{3}}$ & $\underline{4}$ & $\underline{5}$ & \\
\hline Administrator & 0 & 0 & 2 & 3 & 7 & 4.42 \\
\hline HRD Manager & 0 & 0 & 2 & 5 & 5 & 4.25 \\
\hline Instructor/Facilitator & 0 & 1 & 2 & 6 & 3 & 3.92 \\
\hline Program Designer & 0 & 1 & 3 & 6 & 2 & 3.75 \\
\hline Marketer & 1 & 1 & 2 & 6 & 2 & 3.58 \\
\hline Organization Change Agent & 0 & 3 & 3 & 3 & 3 & 3.50 \\
\hline HRD Materials Developer & 1 & 1 & 5 & 3 & 2 & 3.33 \\
\hline Evaluator & 1 & 3 & 3 & 3 & 2 & 3.17 \\
\hline Needs Analyst & 1 & 4 & 1 & 5 & 1 & 3.08 \\
\hline Researcher & 2 & 4 & 2 & 2 & 2 & 2.83 \\
\hline \multicolumn{7}{|l|}{ Individual Career } \\
\hline Development Advisor & 3 & 2 & 4 & 2 & 1 & 2.67 \\
\hline
\end{tabular}


Table 22

Institutional Emphasis Placed Upon HRD Roles By Organization Level

To Which HRD Reports

Third and Fourth Level (Associate/Assistant Vice President, Director, Associate/Assistant Director)

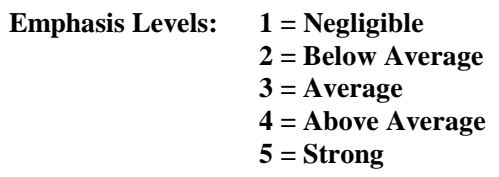

\begin{tabular}{lllllll}
\hline \multirow{2}{*}{ HRD Roles } & \multicolumn{7}{c}{ Frequency of Emphasis Level } \\
Administrator & $\underline{\mathbf{2}}$ & $\underline{\mathbf{3}}$ & $\underline{\mathbf{3}}$ & $\underline{\mathbf{4}}$ & $\underline{\mathbf{5}}$ & Average Emphasis \\
HRD Manager & 0 & 0 & 3 & 2 & 3 & 4.00 \\
Instructor/Facilitator & 0 & 0 & 5 & 2 & 1 & 3.50 \\
Program Designer & 0 & 0 & 5 & 2 & 1 & 3.50 \\
Marketer & 0 & 1 & 3 & 1 & 3 & 3.50 \\
HRD Materials Developer & 0 & 0 & 5 & 2 & 1 & 3.50 \\
Needs Analyst & 1 & 0 & 4 & 2 & 1 & 3.25 \\
Organization Change Agent & 1 & 2 & 0 & 5 & 0 & 3.13 \\
Evaluator & 1 & 2 & 3 & 1 & 1 & 2.88 \\
Researcher & 0 & 2 & 5 & 1 & 0 & 2.88 \\
Individual Career & & & & & & \\
$\quad$ Development Advisor & 2 & 2 & 2 & 1 & 1 & 2.63 \\
\hline & & & & &
\end{tabular}




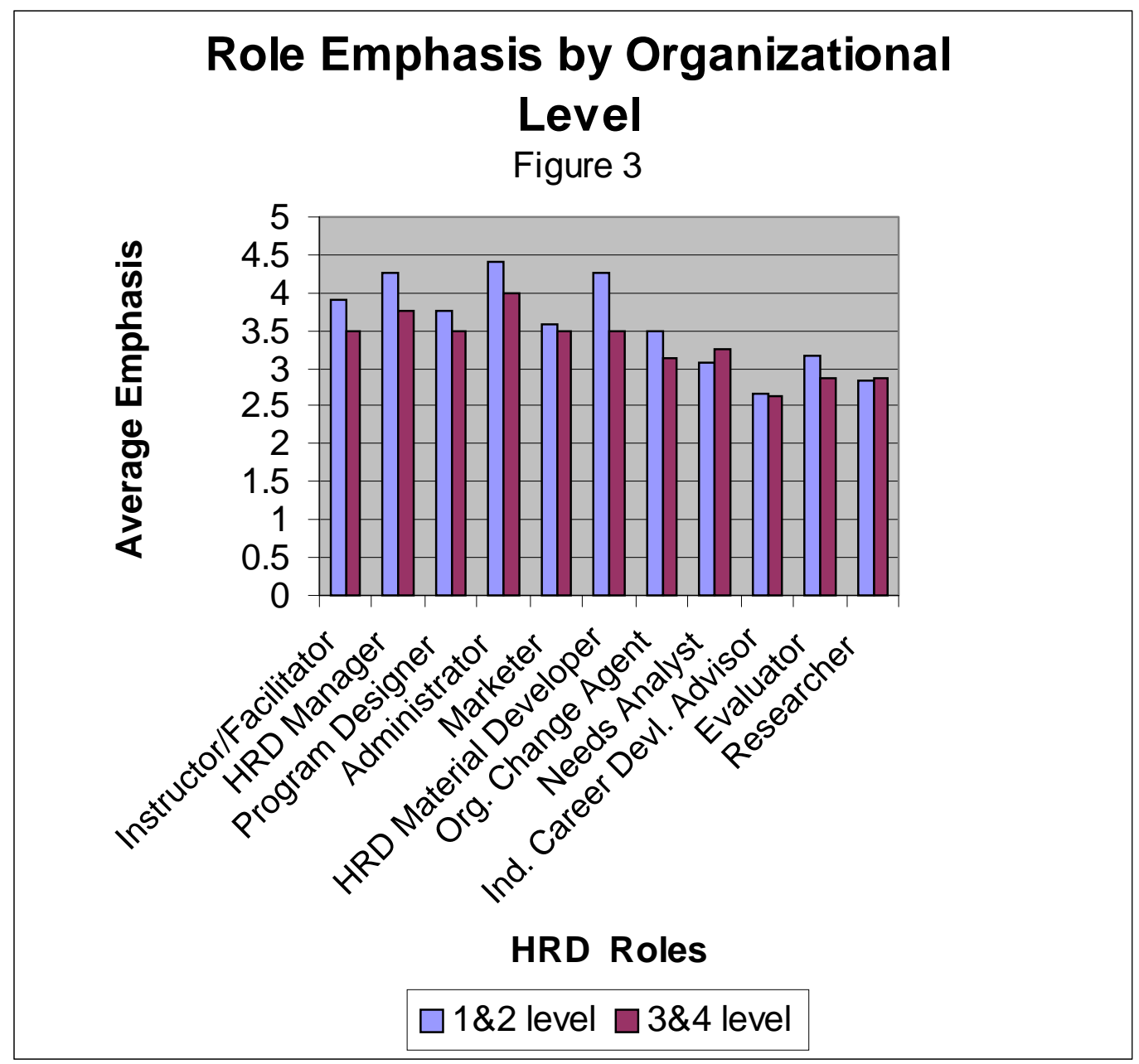




\section{Question 4}

What changes in emphasis does the human resource development person(s) expect for the identified roles of human resource development at the institution in the next decade?

On the Human Resource Development (HRD) Roles Survey, respondents were asked to predict whether the emphasis upon each of the selected HRD roles would increase, decrease, or remain unchanged at their institutions by the year 2010. According to the data in Table 18, the majority of respondents predicted an increase in institutional emphasis on nine of the 11 human resource development roles. There were only three instances of a predicted decrease in an HRD role, and they were received from the same respondent. The greatest frequency of predicted increase in emphasis was for the Organization Change Agent, Evaluator, and Needs Analyst roles. The Administrator and HRD Manager roles received the least frequent predictions of increased emphasis and the most frequent predictions of no change in emphasis.

\section{Question 5}

What specific changes in human resource development are expected to occur at the institutions by the year 2010 ?

In addition to providing predictions of expected increase/decrease in emphasis for the selected human resource development roles, respondents were allowed to answer an open-ended question to predict changes that they expected for HRD at their institutions. Table 19 summarized the emergent category analysis for predicted changes in 
human resource development, and a complete listing of responses to the open-ended question is provided in Appendix G. The qualitative data are consistent with the quantitative responses cited in Table 18 in that both predict an increase in institutional expectations for human resource development activity. More specifically, this increase in HRD activity is expected to result primarily from an increasing need for training and development programs, more involvement in strategic planning, increasing organization change, and advancing technology.

\section{Ancillary Findings}

Gender was not one of the demographic variables studied as part of this research project. However, as an ancillary finding, there appeared to be some differences in both the institutional emphasis placed upon HRD roles and predictions of trends according to the gender of the respondent. The respondent sample was comprised of $45 \%$ male and 55\% female (see Table 7). The average institutional emphasis upon the Administrator, HRD Manager, and Individual Career Development Advisor roles reported by males was somewhat higher than reported by females, while the average emphasis reported by females for the Instructor/Facilitator, Program Designer, HRD Materials Developer, Organization Change Agent, Evaluator, and Researcher roles was noticeably higher than that reported by males. Males tended to predict an increase in emphasis upon the Organization Change Agent and Marketer roles somewhat more often than females, and females were noticeably more frequent than males in predicting an increase in emphasis upon the HRD Materials Developer role. Summaries of institutional emphasis placed 
upon HRD roles and predicted change in emphasis, both by gender of the respondents, are presented in Tables 23 and 24.

Table 23

Summary of Institutional Emphasis Placed Upon HRD Roles By Gender of Respondents

\begin{tabular}{|c|c|c|c|c|c|c|c|}
\hline \multirow[b]{2}{*}{ HRD Roles } & \multicolumn{7}{|c|}{$\begin{array}{l}1=\text { Negligible } \\
2=\text { Below Average } \\
3=\text { Average } \\
4=\text { Above Average } \\
5=\text { Strong }\end{array}$} \\
\hline & \multicolumn{7}{|c|}{ Frequency of Emphasis Level } \\
\hline \multirow{3}{*}{ Administrator } & Gender & $\underline{1}$ & $\underline{2}$ & $\underline{3}$ & $\underline{4}$ & $\underline{5}$ & Av. Emphasis \\
\hline & $\overline{\text { Male }}$ & $\overline{0}$ & $\overline{0}$ & $\overline{2}$ & $\overline{2}$ & $\overline{5}$ & 4.33 \\
\hline & Female & 0 & 0 & 3 & 3 & 5 & 4.18 \\
\hline \multirow[t]{2}{*}{ HRD Manager } & Male & 0 & 0 & 2 & 4 & 3 & 4.11 \\
\hline & Female & 0 & 0 & 3 & 5 & 3 & 4.00 \\
\hline \multirow[t]{2}{*}{ Instructor/Facilitator } & Male & 0 & 0 & 4 & 4 & 1 & 3.67 \\
\hline & Female & 0 & 1 & 3 & 4 & 3 & 3.82 \\
\hline \multirow[t]{2}{*}{ Program Designer } & Male & 0 & 1 & 3 & 5 & 0 & 3.44 \\
\hline & Female & 0 & 0 & 5 & 3 & 3 & 3.82 \\
\hline \multirow[t]{2}{*}{ Marketer } & Male & 0 & 1 & 3 & 3 & 2 & 3.67 \\
\hline & Female & 1 & 1 & 2 & 4 & 3 & 3.64 \\
\hline \multirow[t]{2}{*}{ HRD Mtls. Developer } & Male & 0 & 1 & 7 & 0 & 1 & 3.11 \\
\hline & Female & 1 & 0 & 3 & 5 & 2 & 3.64 \\
\hline \multirow[t]{2}{*}{ Org. Change Agent } & Male & 0 & 4 & 1 & 2 & 2 & 3.22 \\
\hline & Female & 1 & 1 & 2 & 6 & 1 & 3.45 \\
\hline \multirow[t]{2}{*}{ Needs Analyst } & Male & 0 & 3 & 3 & 2 & 1 & 3.11 \\
\hline & Female & 2 & 1 & 2 & 5 & 1 & 3.18 \\
\hline \multirow[t]{2}{*}{ Evaluator } & Male & 1 & 3 & 2 & 2 & 1 & 2.89 \\
\hline & Female & 1 & 2 & 4 & 2 & 2 & 3.18 \\
\hline \multirow[t]{2}{*}{ Researcher } & Male & 1 & 3 & 3 & 1 & 1 & 2.78 \\
\hline & Female & 1 & 3 & 4 & 2 & 1 & 2.91 \\
\hline \multirow{2}{*}{$\begin{array}{l}\text { Individual Career } \\
\text { Development Advisor }\end{array}$} & Male & 2 & 2 & 2 & 2 & 1 & 2.78 \\
\hline & Female & 3 & 2 & 4 & 1 & 1 & 2.55 \\
\hline
\end{tabular}




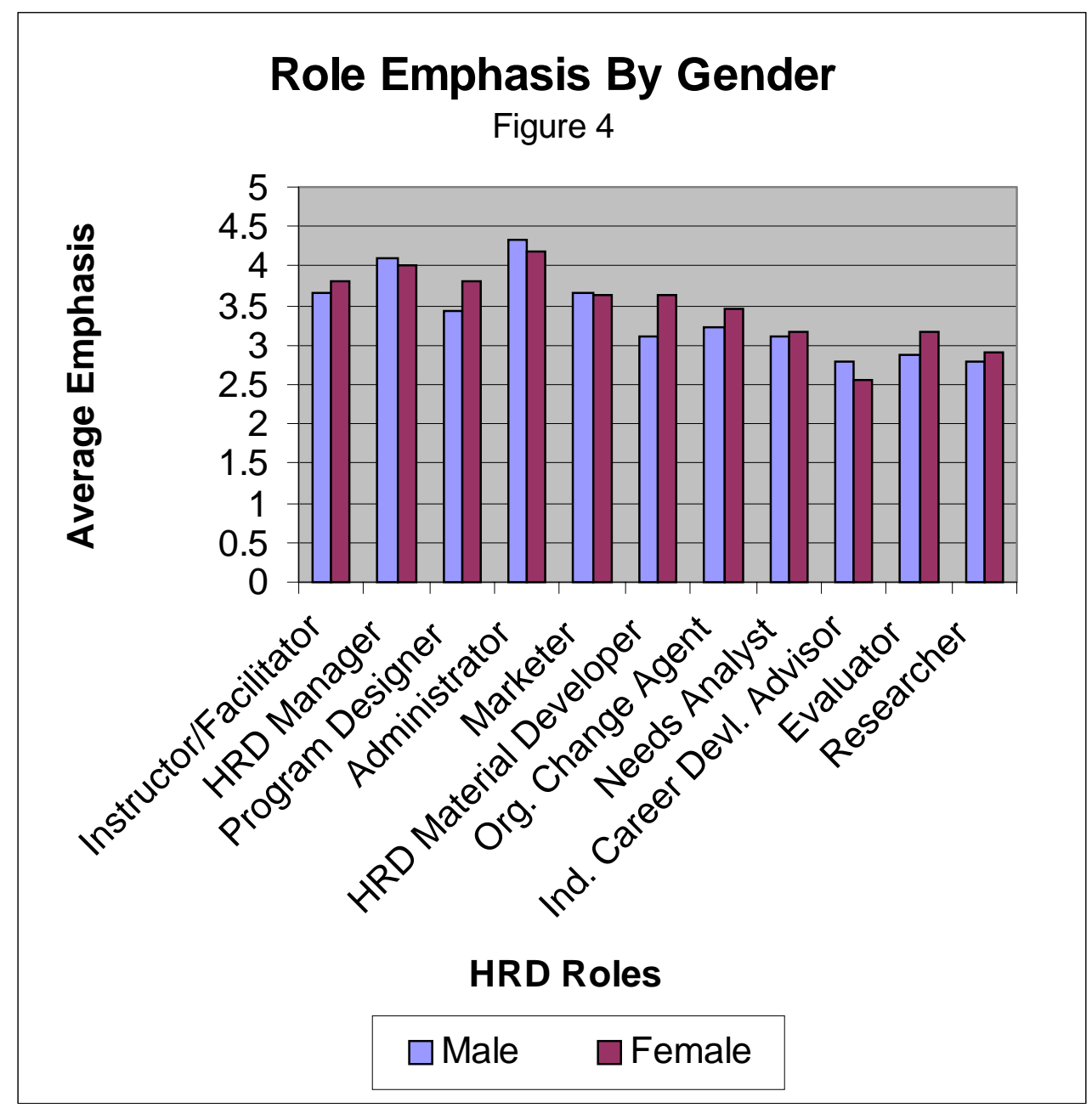




\section{Table 24}

\section{Summary of Predicted Change In Emphasis Upon HRD Roles}

\section{By Gender of Respondents}

\begin{tabular}{|c|c|c|c|c|}
\hline HRD Roles & Gender & Decrease & No Change & Increase \\
\hline \multirow{2}{*}{ Org. Change Agent } & Male & 0 & 0 & 8 \\
\hline & Female & 0 & 2 & 9 \\
\hline \multirow[t]{2}{*}{ Evaluator } & Male & 0 & 1 & 7 \\
\hline & Female & 0 & 1 & 10 \\
\hline \multirow[t]{2}{*}{ Needs Analyst } & Male & 0 & 1 & 7 \\
\hline & Female & 0 & 2 & 9 \\
\hline \multirow[t]{2}{*}{ Researcher } & Male & 0 & 2 & 6 \\
\hline & Female & 0 & 4 & 7 \\
\hline \multirow[t]{2}{*}{ Program Designer } & Male & 1 & 1 & 6 \\
\hline & Female & 0 & 4 & 7 \\
\hline \multirow[t]{2}{*}{ Marketer } & Male & 0 & 2 & 6 \\
\hline & Female & 0 & 5 & 6 \\
\hline \multirow{2}{*}{$\begin{array}{l}\text { Individual Career } \\
\text { Development Advisor }\end{array}$} & Male & 1 & 1 & 6 \\
\hline & Female & 0 & 5 & 6 \\
\hline \multirow[t]{2}{*}{ Instructor/Facilitator } & Male & 0 & 4 & 4 \\
\hline & Female & 0 & 4 & 7 \\
\hline \multirow[t]{2}{*}{ HRD Mtls. Developer } & Male & 1 & 3 & 4 \\
\hline & Female & 0 & 4 & 7 \\
\hline \multirow[t]{2}{*}{ HRD Manager } & Male & 0 & 4 & 4 \\
\hline & Female & 0 & 6 & 5 \\
\hline \multirow[t]{2}{*}{ Administrator } & Male & 0 & 5 & 3 \\
\hline & Female & 0 & 6 & 5 \\
\hline
\end{tabular}

\section{Summary}

This chapter presented an analysis of the data collected to analyze the roles and trends for human resource development at large public universities within the SREB 
geographical area. Data were collected from 20 institutions through administration of the Human Resource Development (HRD) Roles Survey. This survey solicited data to analyze role expectations (institutional emphasis on specific roles) and predictions of trends for selected HRD roles. The survey was designed to obtain valid data to answer research questions regarding reporting hierarchy for human resource development functions, the roles HRD administrators are expected to perform, institutional emphasis placed on the recognized HRD functions, trends expected by the respondents for the HRD roles at their institutions over the next decade, and specific changes in any areas of human resource development at the respondent's university by the year 2010. Frequency distributions, percentages, and emergent category analyses, presented in tabular form, were utilized to organize and examine the data. 


\section{Chapter 5}

\section{Data Analysis}

A number of conclusions can be drawn from the findings in this study. The following is an examination first of the findings regarding each of the five research questions and then regarding the import of those findings in combination.

\section{Research Questions}

The first research question had to do with reporting hierarchy. The HRD function in this study of large, public universities indicated considerable variation in reporting hierarchy. Of 20 respondents, the function reported to four distinctly different organizational levels. A slight majority (55\%) reported to a second-level administrator, usually a vice president who functioned as the institution's chief administration/finance/ business officer. However, $40 \%$ reported to a lower level officer, generally one with broad-based human resource management responsibilities. One respondent reported directly to the institution's top administrator. This variation indicates considerable differences in both staff support and utilization of the function at a strategic level. Recent organizational changes affecting reporting hierarchy were indicated in several of the survey responses. The following conclusions are noted: (1) there is an inconsistency in the organizational level and strategic utilization of the function among the institutions surveyed, (2) organizational changes are occurring which are, and will continue to affect institutional utilization of the function, and (3) in spite of the similarities of institutions surveyed, they are at various stages of organizational change. 
There was also considerable variation in the functions expected to be performed by the person responsible for human resource development. A majority of the

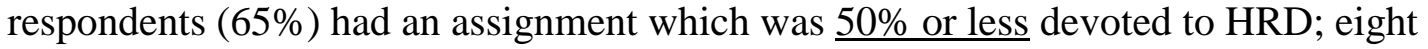
respondents (40\%) had only $1-25 \%$ of their efforts devoted to HRD, and only six (30\%) were devoted full-time to human resource development activities. For those whose positions required attention to activities other than HRD, the great majority were responsible for the other traditional human resource management functions--employment, compensation, benefits, and employee relations; some also had payroll or information systems responsibilities. Conclusions are that: (1) there is a wide range of functional responsibility assigned to the human resource development persons at the institutions surveyed, (2) the majority have responsibilities, although related, which are outside the HRD function, (3) the majority have no more than half their responsibilities specifically in HRD roles, and therefore, (4) the majority of those institutions surveyed do not reflect, from a staffing standpoint, a major strategic focus on human resource development.

Table 25 presents a comparison between the organizational levels to which the HRD function reported and respondent's percent of responsibilities assigned to human resource development roles. There was a tendency for those reporting to higher organizational levels to be assigned a broader range of responsibilities, including functions outside the HRD arena. Conversely, the lower the organizational reporting level, the greater the tendency to assign HRD as a majority responsibility. It can be concluded that (1) the traditional pattern among those organizations surveyed reflects HRD perceived as one of the overall human resource management functions reporting to an administrative vice president, (2) those institutions assigning HRD as a majority or 
full-time responsibility have generally delegated that responsibility to lower organizational levels, and (3) the variations in organizational level to which HRD reports and the extent to which the HRD person concentrates on the function can be attributed to the surveyed institutions' differences in perceived needs, rate of organizational change, and/or responses to an increasing emphasis on human resource development. 
Table 25

Organizational Level to which Human Resource Development Reports Compared to Respondent's Percent of Responsibilities Assigned to HRD*

\begin{tabular}{cccc}
\hline $\begin{array}{c}\text { Organizational Level } \\
\text { \% HRD }\end{array}$ & $\begin{array}{l}\text { Reporting } \\
\text { Frequency }\end{array}$ & $\begin{array}{l}\text { Percent of } \\
\text { Responsibilities } \\
\text { Frequency }\end{array}$ & Percentage \\
\hline First Level (Chancellor/President) & $\mathbf{1}$ & & $\mathbf{5}$ \\
$1-25 \%$ & & 1 & \\
$26-50 \%$ & & 0 & \\
$76-99 \%$ & & 0 & \\
$100 \%$ & & &
\end{tabular}

Second Level (Vice Chancellor/VP)

11

55

$1-25 \%$

5

$26-50 \%$

4

$76-99 \%$

0

$100 \%$

2

Third Level (Assoc./Asst. VP, Dir.) 6

$$
\begin{aligned}
& 1-25 \% \\
& 26-50 \% \\
& 76-99 \% \\
& 100 \%
\end{aligned}
$$

6

Fourth Level (Assoc./Asst. Dir.)

2

10

$$
\begin{aligned}
& 1-25 \% \\
& 26-50 \% \\
& 76-99 \% \\
& 100 \%
\end{aligned}
$$

0

0

0

2 
A major part of the survey instrument was devoted to determining institutional emphasis on the 11 human resource development roles as defined by the American Society for Training and Development. The majority of the respondents were expected to perform all 11 roles to some degree, but there was great variation in emphasis on specific roles, and only four of the roles were expected to be performed by all respondents. On average, the Administrator, HRD Manager, and Instructor/Facilitator roles had the greatest emphasis regardless of the respondent's number of years in HRD or the percent of responsibilities assigned to the function; the Career Development Advisor, Researcher, Evaluator, and Needs Analyst roles had the least average emphasis. At those institutions where HRD reported to the third or fourth organizational level (as opposed to first or second level), there was a noticeable increase in the average emphasis on the roles of Program Designer, Marketer, and HRD Materials Developer. Where HRD reported to the first or second organizational level, there was a noticeably heavier emphasis on the role of Organization Change Agent. From these findings, conclusions are that (1) the institutions generally expect the HRD function to provide most, if not all of the recognized services (roles) of the function to their organization, (2) the greatest average emphasis is on those roles involving the coordination, delivery, supporting, leading, and presentation of existing HRD programs and services, (3) the least average emphasis is on those roles involving assisting individual employees with their developmental needs, determining organizational needs, evaluating existing programs, and identifying new ones to meet those needs, and (4) when HRD reports to higher organizational levels, greater emphasis is given to the role of influencing and supporting change in organizational behavior; when the function reports to lower organizational levels, there tends to be an 
increase in emphasis on designing intervention, producing instructional materials, and promoting HRD services.

Respondents were asked to predict whether the emphasis upon each of the selected HRD roles would increase, decrease, or remain unchanged at their institutions by the year 2010. The majority of respondents who answered this survey question predicted increased emphasis for nine of the 11 roles, and only one respondent predicted any decreases in emphasis. The Administrator and HRD Manager roles were least frequently predicted for increased emphasis; the roles of Organization Change Agent, Evaluator, Needs Analyst, Researcher, and Program Designer (in that order) were most frequently predicted for increased emphasis. From this information, conclusions drawn are that (1) the respondents expect an increase in the human resource development function at their institutions during the next decade; (2) the roles most anticipated for increased emphasis involve influencing and supporting changes in organizational behavior, determining organizational needs, evaluating existing programs, and identifying/designing new programs to meet the needs; (3) in general, there is recognition that the existing strongest emphasis on the Administrator and HRD Manager roles is not in keeping with changing institutional needs, and that a shift in role emphasis must occur to meet those needs [evident by the fact that those two roles are predicted to receive the least increase in emphasis in the next decade]; and (4) some increase in emphasis is expected in the area of individual career development, but a greater shift in emphasis is predicted for the organization development and training and development areas.

In answer to a question regarding specific anticipated HRD changes at the institution by the year 2010, most respondents predicted one or more changes. The 
comments were consistent with the reported predictions of change in role emphasis, and also gave some insight into the respondents' perception of trends affecting change. It can be concluded that respondents expect (a) growth in overall human resources responsibilities, (b) an increase in the number of training and development programs, (c) more involvement in strategic planning, (d) an increase in organization and workforce change, and (e) continued advancing technology and resulting new concepts.

\section{Ancillary Findings}

There appeared to be differences in both the perceived institutional emphasis placed upon HRD roles and predictions of trends according to the gender of the respondent. The respondent sample was $45 \%$ male and $55 \%$ female. The average institutional emphasis on the Administrator, HRD Manager, and Individual Career Development Advisor roles reported by males was somewhat higher than reported by females, while the average emphasis reported by females for the Instructor/Facilitator, Program Designer, HRD Materials Developer, Organization Change Agent, Evaluator, and Researcher roles was higher than that reported by males. Research has shown that gender has an influence on leadership style, and it may account for the differences in perceived role emphasis and trend predictions in this study. However, the differences were not statistically great, and major conclusions are therefore not to be drawn. It could be concluded that females appear to have more of an affinity for the roles which are focused on the training and development area, and males appear to have more of an affinity for roles supporting the administrative and career development areas. 


\section{The 1997 Triplett Study}

As indicated in the review of literature (p. 37), this study was prompted in part by Dr. Beth Triplett's 1997 study of small, private colleges and universities in the SREB area. This study is not a replication, but asked some of the same (or very similar) questions of the large, public universities; therefore, some comparisons can be made of the findings in the two studies.

Triplett found that very little human resource development activities were actually occurring at the small private institutions. This study finds that most of the defined HRD roles are occurring, at least to some degree, at the large public institutions. A logical conclusion is that their size and ability to support more job specialization have made it possible for the larger institutions to become more involved in HRD efforts.

The Triplett study concluded that time spent on the HRD roles by respondents varied greatly by role, that most of those responsible for HRD spent at least half of their time on other functional assignments, and that both the responsibilities and staffing of HRD would increase. This study arrived at similar conclusions for the large public universities, except that there were no indications that the survey respondents expected increased staffing.

Dr. Beth Triplett concluded in summary that there was a mismatch at the institutions surveyed between what was perceived to be important and what had actually been implemented. This study appears to indicate that the large public universities in the SREB area have made more progress in what Brinkerhoff and Gill have called "making the paradigm shift," but that they are still reacting to rapidly changing external forces and in process of bringing HRD organization and programs in line with needs. Unlike the 
small, private institutions, the large, public universities report activity in most, if not all the eleven defined HRD roles; predict increasing emphasis on those roles involving determining organizational needs, identifying/designing new programs to meet the needs, and supporting change in organizational behavior; and report recent organizational changes, activites, and planning that indicate actual implementation of HRD programs to meet priority needs.

\section{Difficulty in Defining HRD}

Rothwell and Sredl maintain that human resource development is difficult to define and that many people, including the practitioners themselves, continue to use the term loosely (Rothwell \& Sredl, 1992). McLagan agrees, and offered five major reasons: HRD is an emerging field, a dynamic field, relies on more than one subject matter, exists within the larger human resource (HR) arena, and is pervasive (McLagan, 1989). This difficulty in defining the function, and the emergent, dynamic nature of the field is borne out in this study by (1) variations in organizational level to which the function reports, (2) the large percentage of practitioners assigned responsibilities other than HRD, (3) the considerable variation in role emphasis, and (4) the many predictions of growth in overall HR responsibilities and increased emphasis on most defined HRD roles.

\section{Summary}

This was a descriptive study designed to assess human resource development role expectations and predicted trends at selected large public universities within the Southern Regional Education Board geographical area. The summary profile for the average 
institutional demographics of the organizations studied was found to be that of a public, four-year university awarding at least 100 doctoral degrees broadly distributed among $10+$ categories, having an enrollment of approximately 27,000 students, an approximate headcount of 7,000 employees, and an annual educational and general expenditure (E\&G) budget of approximately $\$ 446$ million.

In summary, the following 23 conclusions have been determined:

1. There is an inconsistency in the organizational level and strategic utilization of the HRD function among the institutions surveyed.

2. Organizational changes are occurring which are, and will continue to affect institutional utilization of the function.

3. In spite of the demographic similarities of institutions surveyed, they are at various stages of organization development and change.

4. There is a wide range of functional responsibility assigned to the human resource development persons at the institutions surveyed.

5. The majority of the HRD persons have responsibilities, although related, which are outside the HRD function.

6. The majority of the HRD persons have no more than half their responsibilities specifically in HRD roles.

7. The majority of the institutions surveyed do not reflect, from a staffing standpoint, a major strategic focus on human resource development.

8. The traditional pattern among organizations surveyed reflects HRD perceived as one of the overall human resource management functions reporting to an administrative vice president. 
9. Those institutions assigning HRD as a majority or full-time responsibility have generally delegated that responsibility to lower organizational levels.

10. The variations in organizational level to which HRD reports and the extent to which the HRD person concentrates on the function can be attributed to the institutions' differences in perceived needs, rate of organizational change, and/or responses to an increasing emphasis on human resource development.

11. The institutions generally expect the HRD function to provide most, if not all the recognized services (roles) of the function to their organization.

12. The greatest average institutional emphasis is on those roles involving coordination, delivery, supporting, leading, and presentation of existing HRD programs and services.

13. The least average emphasis is on those roles involving assisting individual employees with their developmental needs, determining organizational needs, evaluating existing programs, and identifying new ones to meet those needs.

14. When HRD reports to higher organizational levels, greater emphasis is given to the role of influencing and supporting change in organizational behavior; when the function reports to lower organizational levels, there tends to be an increase in emphasis on designing intervention, producing instructional materials, and promoting HRD services.

15. The respondents expect an increased emphasis on the human resource development function at their institutions during the next decade.

16. The roles expected to receive the greatest increase in emphasis involve influencing and supporting changes in organizational behavior, determining 
organizational needs, evaluating existing programs, and identifying/designing new programs to meet the needs.

17. In general, there is recognition that the existing heavy emphasis on Administrator and HRD Manager roles is not in keeping with changing institutional needs, and that a shift in role emphasis must occur to meet those needs.

18. Some increase in emphasis is predicted for the area of individual career development, but a greater shift in emphasis is expected for the organizational development and training and development areas.

19. Respondents expect (a) growth in overall human resources responsibilities, (b) an increase in the number of training and development programs, (c) more involvement in strategic planning, (d) an increase in organization and workforce change, and (e) continued advancing technology and resulting new concepts.

20. Female respondents appear to have more of an affinity for roles in the area of training and development, and males respondents appear to have more of an affinity for roles supporting the administrative and career development areas.

21. Most of the defined HRD roles are occurring to some degree at the institutions surveyed. This is in contrast to Triplett's findings at the small, private SREB institutions, and the size and ability to support job specialization at the large universities is almost certainly a factor.

22. In spite of predicted growth of the function and increased emphasis on many HRD roles, survey respondents do not appear to expect increased staffing.

23. Human resource development is difficult to define as a function because it is emerging, dynamic, relies on more than one subject matter, exists within the larger HR 
arena, and is pervasive. This difficulty in definition is borne out by (a) variations in organizational level to which the function reports, (b) the large percentage of practitioners assigned responsibilities other than $\mathrm{HRD}$, (c) the considerable variation in role emphasis, and (d) the many predictions of growth in overall HR responsibilities and increased emphasis on most defined HRD roles. 


\section{Chapter 6}

\section{Recommendations}

Based on the literature and data collected as part of this research study, the following actions are recommended:

\section{For Institutions and Practitioners}

1. Universities should increase the importance and utilization of their human resource development functions on campus. The majority of fiscal resources are dedicated to the salary and benefits of employees, and HRD efforts are designed to improve both individual and organizational effectiveness. Susan Ginsberg of the National Association of College and Business Officers (NACUBO) said, "Colleges and universities, with their focus on teaching, research, and community service, tend to forget that they are also employers" (Ginsberg, 1993). Organizations in higher education should make certain they are taking human resource development as seriously as tuition revenue, annual funds, and plant maintenance.

\section{Universities should assign full-time human resource development} responsibilities to an officer of the institution. This will enhance concentrated effort on the defined roles of HRD, move toward meeting predicted needs in those functional areas, and send a clear message to the university community of the importance of HRD.

\section{Universities should assign the full-time HRD officer to the highest}

organizational level possible. Ideally, this officer should report to the president, but when that isn't feasible, the HRD person should report to a vice president, on a separate and equal organizational level with the human resource management officer who is 
responsible for other traditional HR functions (i.e., employment, benefits, compensation, employee relations). This will provide better input to the organization's strategic planning, and also help clarify an understanding of the function as encompassing not only training and development areas, but organization development and career development as well.

\section{Universities should find ways to devote more fiscal support (staffing and} operating budget) to the HRD function. There are widespread budget constraints among the institutions and an impetus to cut costs rather than increase spending. However, there needs to be understanding and support of the premise that a well-organized and productive HRD function will make the organization's most valuable asset much more cost effective in the long run. Changing an organization's culture from an environment characterized by traditional program-driven training to one of system-driven training and participative strategic planning is a lengthy process requiring organization-wide participation, many activities, and considerable fiscal support. The payoff is added value to individuals, teams, and the organization as a human system-members of the organization who are more versatile, flexible, and can accomplish both their own goals and those of the organization in a time of accelerating change. Pressures for productivity will intensify. Focus will continue to shift to the customer and quality. The arena for planning and action will be global. Business strategies will become more dependent on the quality and versatility of the human resource. Without the necessary support for a myriad of culture-change activities, the workforce of the future will not have kept pace, and both efficiency and effectiveness will suffer greatly. 
5. HRD administrators should continue to expand their scope of activities, ensure that they are functioning in areas of human resource development, and work toward performing all the 11 roles defined in Models for HRD Practice.

\section{Human resource development administrators need to be as concerned as} any other university officer with competitiveness and effectiveness. They need to perform their functions in a way that takes into account the financial, strategic, and technological goals of the institution; they must work to serve as effective members of the management team.

7. Human resource development officers must strive to build a climate of organizational learning. HRD professionals can help by creating an infrastructure for learning and application of learning; the "employee/learner" is not as pervasive on most campuses as might be assumed. Knowles (1973) advocated the establishment of an environment for learning, and the HRD administrator can exert major influence in creating that climate on campus; the adult learner has been neglected, and the HRD administrator can and should change that situation for the employee learner.

8. HRD administrators must identify closely with the mission and values of the institution and encourage others at all organizational levels to take a systemic view and look at issues holistically. Some of the greatest opportunities for performance improvement lie in an organization's functional interfaces.

9. HRD administrators should work to gain a better understanding from their superiors of the priority placed on selected HRD roles. This study has indicated considerable variation in institutional emphasis upon the defined roles, ambiguous or management-related assignments, and apparent misunderstandings regarding specific 
roles. Practitioners must help the chief administrators understand the comprehensive nature of the human resource development function, and seek institutional support for performing all the selected roles as a regular part of the position.

10. HRD administrators should begin (or continue to) assess, quantify, and provide clear and tangible data regarding development efforts and their effects as one of the ways to communicate information to top decision makers.

11. HRD administrators should rewrite their own job descriptions to provide clarity regarding the functions/roles expected of them. The practitioners have the best understanding of the comprehensive nature of a function spanning training and development, organization development, and career development; with supervisory approval, they are best suited to distinguish the development components and clarify the responsibilities.

\section{Human resource development administrators should pressure the} associations which most closely represent them for additional resources and attention. The College and University Personnel Association (CUPA) has traditionally focused on the personnel and human resource management aspects of HR and has offered little in the HRD area. Even though the majority of HRD administrators are supervised by the chief business officer, the National Association of College and University Business Officers (NACUBO) provides minimal resources. Both the Society for Human Resource Management (SHRM) and the American Society for Training and Development (ASTD) have seldom included educational institutions in their research and publications, presumably because of the scant presence of HRD on campuses (Triplett, 1997). These organizations offer the potential for networking, professional development and strategy 
advice that is lacking for practitioners in higher education.

\section{For Further Study}

\section{Future studies should make even greater efforts to define human} resource development and distinguish it from human resource management activities. Triplett's study contained the same recommendation. In spite of attempts to clarify the difference on the survey instrument in this study and telephone conversations in many instances with the respondents, there were a number of indications in the material submitted that confusion existed in separating the two closely related functions.

\section{Gender should be included as one of the demographic variables studied} in future research. This, too, was a recommendation in the Triplett study. Although this study did not focus on gender to address the problem questions, the ancillary findings (p. 78) suggest that responses to institutional role emphasis and trend predictions may vary significantly based upon gender of the respondent.

\section{Future studies should request additional, specific information regarding} the institution's change efforts. This study requested predictions of change, but not the actual efforts being made to influence or effect change; consequently, few respondents cited such efforts.

\section{Future studies should seek responses indicating percentage of time}

actually spent on each role. This study requested indications of institutional emphasis on each role, which is a useful general comparator; however, estimates of actual time spent on a specific function (probably utilizing ranges of time) during a measured period would provide a more accurate picture of what is actually being performed. 
5. There should be replications of this study for other geographical areas of the United States and/or the nation as a whole. Shared information and comparisons of expectations and trends in the field with institutions outside the SREB could be of great value to practitioners and administrators on "both sides" of the comparisons.

\section{Future research should replicate the ASTD study on which role} definitions were based and provide a new edition of the Models for HRD Practice. The models were produced six years after the Models for Excellence report, and in that time period a number of revisions/improvements occurred. It has now been ten years since the study on which the present models are based; in light of continued rapid change in higher education and the workforce, it would seem logical to undertake another revision and update the HRD roles to address contemporary expectations.

\section{Researcher's Insights}

The writer has been a human resource practitioner for over 40 years, functioning in various human resource management assignments for five different employers, three of which have been mid-size to large public universities. The other two employers provided experience in the private sector, both manufacturing and financial services, where profit was the "bottom line." The comparisons have been interesting and enlightening, and a study over time of differences in the rate of change in different organizations as they evolve and strive to respond to the forces that drive them.

It has been my experience that business organizations respond to external forces and change much more rapidly than institutions of higher education, probably because their very life has depended upon it. Private sector employers were painfully aware of 
the economics of supply and demand and the absolute necessity of customer service.

Decisions effecting organizational change were made more quickly, and the culture was one of encouraging risk and accepting a limited number of mistakes, as long as corrections were made thereafter and the mistakes viewed as a learning experience. This culture has been evident in the more successful businesses for a very long time.

In my perception and experience, higher education has traditionally been a very structured system, comfortable in its "think tank" tradition, very careful about changing anything that would impact established procedures, processes, and the freedom to continue teaching, doing research, and providing community services in the way that it is accustomed. There are well defined classifications of faculty, staff and administration. The system is compartmentalized and often quite territorial. There is a faculty handbook and a classified staff handbook. The institutional advancement office raises whatever money is not provided by state funding, and the business officer often "determines" the budget. Everyone is a specialist, which is both good and bad.

Specialization has great value to an organization from the standpoint of providing the support and attention to various activities and programs necessary to accomplish important goals. Indeed, one of the recommendations resulting from this study is the assignment of full-time human resource development responsibilities to an officer of the institution. Specialization is bad to the extent that it gets in the way of wholistic thinking, system-wide strategic planning, and team efforts toward organizational goals.

Higher education training and development efforts often perpetuate this separation; professional development opportunities typically entrench employees further into their specialization area. Faculty attend conferences in their academic discipline. 
Once established, both academic and support programs become sacrosanct, grow easily, and become extremely difficult to downsize or remove, even when all indications are that such action would be in the best interest of the institution as a whole. In short, a culture of this nature makes positive organizational change efforts slow and painful.

The results of this study seem to indicate that the large public universities in the SREB area are indeed beginning to address needed organizational change even if there is yet much to be done. There is obviously a growing recognition that such external forces as growing competition for students (customers), restrictions in available funding, and tremendous advances in technology are making organizational change and systemic planning absolutely necessary, and will continue to do so.

There is great potential for higher education to imitate the "learning organization" applications to be found in the business sector. The external pressures to reduce costs and become more customer service oriented can help force a re-examination of the traditional models in academia. The result cannot help but breathe new life into the system, invigorate the employees, and stimulate the students, who would share in the organizational learning paradigm.

It is one thing to recognize the need for change, to learn new approaches, and even to become convinced that a particular action is the solution of choice. It is quite another thing to take the action when risks are evident, tradition looms, and the naysayers are reluctant. Organizational and administrative support is required for the culture change, and there are many indications that it is present and growing. We are catching up! Long live the positive "business" of higher education, and meeting the ever changing needs of the people we serve! 


\section{References}

Argyris, C. \& Schon, D. A. (1996). Organizational learning II: Theory, method and practice. Reading, MA: Addison-Wesley Publishing Co.

Backoff, R. W. \& Mitnick, B. M. (1981, September). The systems approach, incentive relations, and university management. In J. A. Wilson (Ed.), Management science applications to academic administration. New Directions for Higher Education, $\underline{35}$ (pp. 73-92). San Francisco, CA: Jossey-Bass, Inc.

Barnard, C. I. (1938). The functions of the executive. London: Oxford University Press Beltz, W. A. (Ed.). (1996, Jan. 4). Special Survey Report: Human Resources Outlook. Bulletin to Management; BNA Policy and Practice Series, 47 (1), pp. 1-15.

Bergmann, T. J., Close, M. J. \& Will, T. J. (1992, Winter). Preparing to enter and succeed in human resource management. SAM Advanced Management Journal, 57(1), pp. 36-40. Betts, F. (1992, November). How systems thinking applies to education. Educational Leadership, 50 (3), pp. 38-41.

Blake, R. R. \& Mouton, J. S. (1964). The managerial grid. Houston, TX: Gulf Publishing Co.

Blake, R. R., Mouton, J. S. \& Williams, M. S. (1981). The academic administrator grid. San Francisco, CA: Jossey-Bass Publishers.

Bouchard, R. A., Davidson, H. C. \& Fortunato, R.. T. (1992, Spring). Total organizational personnel accounting study: a study of higher education human resource 
staffing in large institutions. CUPA Journal, 43 (1), pp. 17-23.

Boyett, J. H. \& Conn, H. P. (1991). Workplace 2000: Essential strategies for the new American corporation. New York, NY: Penguin Books.

Brinkerhoff, R. O. \& Gill, S. J. (1994). The Learning Alliance: Systems Thinking In Human Resource Development. San Francisco: Jossey-Bass, Inc.

College and University Personnel Association. (1997). Membership directory and resource guide. Washington, DC.

Craig, R. L. (1976). Training and development handbook: A guide to human resource development (2nd ed.). New York, NY: McGraw-Hill Book Company.

Craig, R. L. (Ed.). (1996). The ASTD training and development handbook (4th ed.). New York, NY: The McGraw-Hill Companies, Inc.

Drucker, P. F. (1990). Managing the Non-profit Organization. New York: HarperCollins Publishers.

Fortunato, R. T., Greenburg, J. A. \& Waddell, G. (1987). Human Resource Development and Personnel Administration. In M. W. Peterson (Ed.), Key Resources on Higher Education Governance, Management and Leadership (pp. 238-262). San Francisco, CA: Jossey-Bass, Inc.

Fortunato, R. T. \& Waddell, G. (1981). Personnel Administration in Higher Education. San Francisco, CA: Jossey-Bass, Inc.

Gilley, J. W. \& Eggland, S. A. (1989). Principles of human resource development. Reading, MA: Addison-Wesley Publishing Co., Inc. 
Ginsburg, S. G. (1993). Paving the way for the 21st century: The human factor in higher education financial management. Washington, DC: National Association of College and University Business Officers.

Hall, R. H. (1987). Organizations: Structures, processes \& outcomes (4th ed.). Englewood Cliffs, NJ: Prentice-Hall, Inc.

Harkness, C. A. (1965). College staff personnel administration. Urbana, IL: College and University Personnel Association.

Hersey, P. \& Blanchard, K. H. (1977). Management of organizational behavior: utilizing human resources (3rd ed.). Englewood Cliffs, NJ: Prentice-Hall, Inc.

Herzberg, F., Mausner, B. \& Snyderman, B. S. (1959). The motivation to work. New York, NY: Wiley.

Jackson, J. H., Morgan, C. P. \& Paolillo, J. G. P. (1986). Organization theory: A macro perspective for management (3rd ed.). Englewood Cliffs, NJ: Prentice-Hall.

Jackson, S. E. \& Schuler, R. S. (1995). Understanding Human Resource Management In the Context of Organizations and Their Environments. Annual Review of Psychology, 45, pp. 237-264.

Katz, D. \& Kahn, R. L. (1978). The social psychology of organizations (2nd ed.). New York, NY: John Wiley \& Sons.

Kimmerling, G. F. (1989, June). The future of HRD. Training \& Development Journal, 43 (6), pp. 46-55.

Knowles, M. S. (1973). The adult learner: A neglected species. Houston, TX: Gulf Publishing Co. 
Mackie, D. (1990, May). Personnel's Role on the Campus. Personnel

Management, 22 (5), pp. 54-59.

Marsick, V. J. \& Watkins, K. E. (1994, Winter). The learning organization: An integrative vision for HRD. Human Resource Development Quarterly, 5 (4), pp. 353-360.

Maslow, A. H. (1943). A theory of human motivation. Psychological Review, (50), pp. 370-396.

McGregor, D. (1960). The human side of enterprise. New York, NY:

McGraw-Hill Book Company, Inc.

McLagan, P. \& Bedrick, R. (1983). Model for excellence. Alexandria, VA:

ASTD Press.

McLagan, P. \& Suhadolnik, D. (1989). Models for HRD Practice. Alexandria, VA: American Society for Training and Development.

McLagan, P.A. (1989, September). Models for HRD Practice. Training \& Development Journal,43 (9), pp.49-59.

Miner, J. B. (1980). Theories of organizational behavior. Hinsdale, IL: The Dryden Press.

Mirvis, P. H., ed. (1993). Building the Competitive Workforce. New York: John Wiley \& Sons, Inc.

Nadler, L. (1970). Developing human resources. Houston, TX: Gulf Publishing Company.

Nadler, L. (1984). Handbook of human resource development. New York, NY: John Wiley \& Sons. 
Perrow, C. (1973, Summer). The short and glorious history of organizational theory. Organizational Dynamics, pp. 2-15.

Pew Higher Education Research Program. (1993, February). A call to meeting. Policy Perspectives (4,4, Section A). Philadelphia, PA: Author.

Pew Higher Education Research Program. (1993, February). Toward restructuring: Assessing the impact of budgetary constraints on college and university operations. Philadelphia, PA: Author.

Pew Higher Education Research Program. (1993, October) An Uncertain Terrain. Philadelphia, PA: Author.

Pynes, J. E. (1997). Human resources management for public and nonprofit organizations. San Francisco, CA: Jossey-Bass, Inc.

Rothwell, W.J. \& Sredl, H.J. (1992). ASTD Reference Guide to Professional Human Resource Development Roles and Competencies, Volume I \& II (2nd ed.). Amherst, MA: HRD Press, Inc.

Rubenstein, A. H. \& Haberstroh, C. J., (Eds.), (1966). Some theories of organization. Homewood, IL: The Dorsey Press.

Schmuck, R. A. \& Runkel, P. J. (1985). The handbook of organization development in schools (3rd ed.). Prospect Heights, IL: Waveland Press, Inc.

Singer, M. G. (1990). Human resource management. Boston, MA: PWS-Kent Publishing Co.

Society for Human Resource Management Foundation. (1990). The competency initiative: Standards of excellence for human resource executives. Alexandria, VA: 
Author.

Taylor, F. W. (1911). The principles of scientific management. New York, NY: Harper \& Brothers Publishers.

Triplett, B. (1997). Role Expectations and Predictions of Trends for Human $\underline{\text { Resource Development at Small, Private Colleges and Universities Within the Southern }}$ Regional Education Board Area. (Doctoral Dissertation). West Virginia University.

Ulrich, D., Brockbank, W. \& Yeung, A. (1989, November). HR competencies in the 1990s. Personnel Administrator, 34 (11), pp. 91-93. 
APPENDICES 
APPENDIX A

\section{LIST OF SREB I INSTITUTIONS}


APPENDIX A

SREB-State Data Exchange

September, 1997

\section{Public Four-Year Institutions}

\section{Four-Year I}

$\begin{array}{ll}\text { AL } & \text { Auburn University } \\ \text { AL } & \text { University of Alabama } \\ \text { AR } & \text { University of Arkansas Main Campus } \\ \text { FL } & \text { Florida State University } \\ \text { FL } & \text { University of Florida } \\ \text { FL } & \text { University of South Florida } \\ \text { GA } & \text { Georgia State University } \\ \text { GA } & \text { University of Georgia } \\ \text { KY } & \text { University of Kentucky } \\ \text { LA } & \text { Louisiana State University } \\ \text { MD } & \text { University of Maryland, College Park } \\ \text { MS } & \text { Mississippi State University } \\ \text { NC } & \text { North Carolina State University } \\ \text { NC } & \text { University of North Carolina, Chapel Hill } \\ \text { OK } & \text { Oklahoma State University Main Campus } \\ \text { OK } & \text { University of Oklahoma Norman Campus } \\ \text { SC } & \text { University of South Carolina, Columbia } \\ \text { TN } & \text { University of Tennessee, Knoxville } \\ \text { TX } & \text { Texas A \& M University } \\ \text { TX } & \text { Texas Tech University } \\ \text { TX } & \text { University of Houston } \\ \text { TX } & \text { University of North Texas } \\ \text { TX } & \text { University of Texas, Austin } \\ \text { VA } & \text { University of Virginia } \\ \text { VA } & \text { Virginia Polytechnic Inst. \& State University } \\ \text { WV } & \text { West Virginia University } \\ \end{array}$




\section{APPENDIX B}

\section{HUMAN RESOURCE DEVELOPMENT \\ (HRD) ROLES SURVEY INSTRUMENT}




\section{Human Resource Development (HRD) Roles Survey}

Please answer the following questions about your institution:

1. Name of Institution:

2. State:

PLEASE NOTE: In this survey, human resource development is being defined as the functions of identifying both employee and organizational needs, designing and delivering education and training programs, and evaluating results, rather than the other traditional personnel management functions, such as employment, employee benefits, job classification and compensation, and employee relations.

3. At the institution, are there units and/or individuals assigned to the human resource development role? $\square$ Yes $\square$ No If yes, please continue. If no, please stop and return survey.

4. Total student enrollment (headcount--full-time \& part-time):

5. Total number of employees (headcount-full-time \& part-time):

6. Total E\&G expenditures as reported on FY98 federal IPEDS financial report: \$

\section{Please answer the following questions about yourself:}

7. Your name and job title:

8. Number of years in current position (include this year):

9. Number of years at current institution (include this year):

10. Total number of years in any

human resource development role (include this year):

11. Gender: $\square$ Male $\square$ Female

12. Highest educational level: $\square$ High School Associate's (Major:

Bachelor's (Major

D Doctorate (Major: ) other (list)

\section{Please answer the following questions about your position:}

13. Job title of person to whom you report:

14. Is your position: $\square$ Full-time $\square$ Part-time $\square$ Numberef hours per week:

15. Percent of your responsibilities assigned to human resource development roles:
a $1-25 \%$
D $26-50 \%$
प $51-75 \%$
口 $76-99 \%$
$\square 100 \%$

If less than $100 \%$, please list other areas of responsibilities: 


\begin{tabular}{|c|c|c|c|c|c|c|c|c|}
\hline \multirow{2}{*}{$\begin{array}{l}\text { Human resource development } \\
\text { Roles } \\
\text { (as defined by ASTD) } \\
\begin{array}{l}\text { 16. Researcher } \\
\text { (Identifying/developing/testing new information) }\end{array}\end{array}$} & \multicolumn{5}{|c|}{$\begin{array}{c}\text { In general, emphasis placed } \\
\text { upon role by institution } \\
\text { (I=negligible; } 2=\text { below average; } \\
3=\text { average; } 4=\text { above average; } \\
5=\text { strong) } \\
\text { [circle correct number] }\end{array}$} & \multicolumn{3}{|c|}{$\begin{array}{l}\text { Expect increase/decrease } \\
\text { in emphasis by the year } \\
\qquad 2010 \\
\text { (l=decrease; } 2=\text { no change; } \\
3=\text { increase) } \\
\text { [circle correct number] }\end{array}$} \\
\hline & 1 & 2 & 3 & 4 & 5 & 1 & 2 & 3 \\
\hline $\begin{array}{l}\text { 17. Marketer } \\
\text { (Promoting HRD services/programs) }\end{array}$ & 1 & 2 & 3 & 4 & 5 & 1 & 2 & 3 \\
\hline $\begin{array}{l}\text { 18. Organization Change Agent } \\
\text { (Influencing/supporting change in org. behavior) }\end{array}$ & 1 & 2 & 3 & 4 & 5 & 1 & 2 & 3 \\
\hline $\begin{array}{l}\text { 19. Needs Analyst } \\
\text { (Analyzing ideal/actual performance) }\end{array}$ & 1 & 2 & 3 & 4 & 5 & 1 & 2 & 3 \\
\hline $\begin{array}{l}\text { 20. Program Designer } \\
\text { (Preparing objectives/designing intervention) }\end{array}$ & 1 & 2 & 3 & 4 & 5 & 1 & 2 & 3 \\
\hline $\begin{array}{l}\text { 21. HRD Materials Developer } \\
\text { (Producing instructional materials) }\end{array}$ & 1 & 2 & 3 & 4 & 5 & 1 & 2 & 3 \\
\hline $\begin{array}{l}\text { 22. Instructor/Facilitator } \\
\text { (Presenting info./directing learning processes) }\end{array}$ & 1 & 2 & 3 & 4 & 5 & 1 & 2 & 3 \\
\hline $\begin{array}{l}\text { 23. Individual Career Development Advisor } \\
\text { (Assisting individuals/assessment,goals,planning) }\end{array}$ & 1 & 2 & 3 & 4 & 5 & 1 & 2 & 3 \\
\hline $\begin{array}{l}\text { 24. Administrator } \\
\text { (Providing coordination/delivery of HRD services) }\end{array}$ & 1 & 2 & 3 & 4 & 5 & 1 & 2 & 3 \\
\hline $\begin{array}{l}\text { 25. Evaluator } \\
\text { (Identifying impact of intervention/effectiveness) }\end{array}$ & 1 & 2 & 3 & 4 & 5 & 1 & 2 & 3 \\
\hline $\begin{array}{l}\text { 26. HRD Manager } \\
\text { (Supporting/leading HRD staff work) }\end{array}$ & 1 & 2 & 3 & 4 & 5 & 1 & 2 & 3 \\
\hline
\end{tabular}

27. What changes do you expect to occur in human resource development at your institution by the year 2010 ?

If possible, please include an organizational chart for personnel administration/HRD units and encircle or highlight those positions or units that perform any of the HRD roles as defined above.

Please attach a business card or include your address if you would like a summary of the results.

Return to: Drayton Justus, Assistant to the Vice President for Administration, Finance, \& Human Resources West Virginia University, P.0.Box 6557, Morgantown, WV 26506, FAX No. (304) 293-2216

\section{Thank you!}


APPENDIX C

COVER LETTER TO

CHIEF HUMAN RESOURCES OFFICERS 


\section{West Virginia University}

College of Human Resources and Education

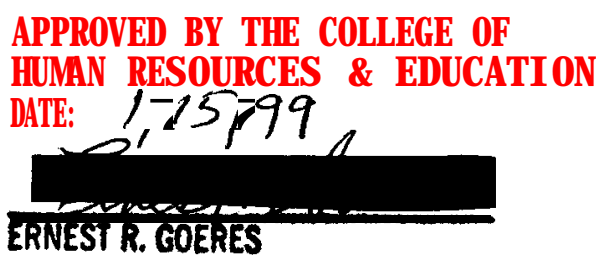

February 1, 1999

Dear Human Resources Administrator:

As part of my doctoral program I am conducting research as to what extent human resource development functions are conducted at large public universities within the Southern Regional Education Board (SREB) geographic region. Enclosed you will find a Human Resource Development Roles survey which will be used to gather data for my doctoral dissertation.

You have been identified as the person at your institution who most closely holds a human resource development role. This would include training and development, needs assessment, program design and organizational change functions conducted for the institution's employees. I would appreciate it if you would complete the enclosed two-page survey about the human resource development role at your institution.

Participation in this research in whole or in part is voluntary, and respondents may choose to leave any question on the survey unanswered. Data will be reported in aggregate form only, and the confidentiality of the institution and respondent will be maintained.

I appreciate your assistance with this research. Thank you for your cooperation.

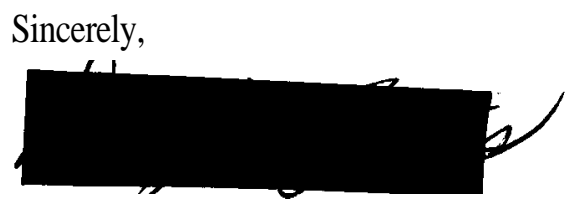

Drayton Justus

Doctoral Student 
APPENDIX D

\section{LIST OF INSTITUTIONS}

RESPONDING TO SURVEY 


\section{Institutions Responding to Survey}

Institution

Auburn University

University of Alabama

University of Arkansas

Florida State University

University of Florida

Georgia State University

University of Georgia

Louisiana State University

University of Maryland

Mississippi State University

University of North Carolina

University of Oklahoma

University of Tennessee

Texas A \& M University

Texas Tech University

University of Houston

University of North Texas

University of Texas

Virginia Polytechnic Inst. \& State University

West Virginia University

\section{Location}

Auburn University, Alabama

Tuscaloosa, Alabama

Fayetteville, Arkansas

Tallahassee, Florida

Gainesville, Florida

Atlanta, Georgia

Athens, Georgia

Baton Rouge, Louisiana

College Park, Maryland

Mississippi State, Mississippi

Chapel Hill, North Carolina

Norman, Oklahoma

Knoxville, Tennessee

College Station, Texas

Lubbock, Texas

Houston, Texas

Denton, Texas

Austin, Texas

Blacksburg, Virginia

Morgantown, West Virginia 
APPENDIX E

HUMAN RESOURCE WHEEL 


\section{Figure 1. Human Resource Wheel}

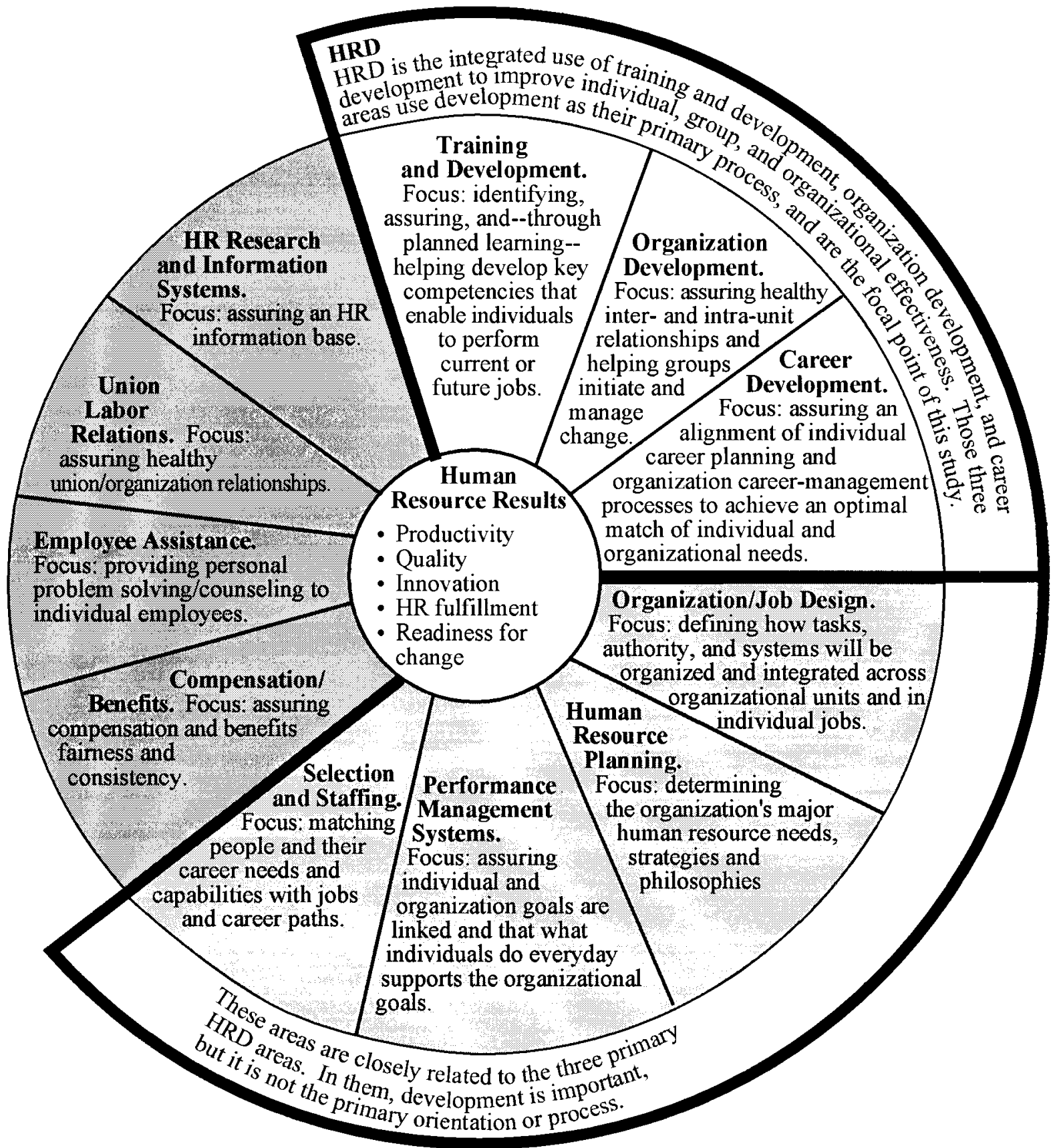

(McLagan \& Suhadolnik, 1989, p.18)

Reprinted from Models for HRD practice. Copyright 1989, the American Society for Training and Development. Reprinted with permission. All rights reserved. 
APPENDIX F

ASTD PERMISSION TO REPRINT

THE HUMAN RESOURCE WHEEL 
American Society for

Training \& Development
Delivering Performance

in a Changing World
1640 King Street

Box 1443

Alexandria, VA 22313-2043

$\mathrm{PH} 703.683 .8100$

FX 703.683.8103

www.astd.org

March 30, 1999

Mr. Drayton R. Justus

Morgantown, WV 26501

Dear Mr. Justus:

Thank you for your letter requesting permission to reproduce material from one of ASTD's publications. ASTD would be pleased to have you reprint the material for noncommercial purposes only.

Please give credit to the authors, and include the following credit line on the material that is reproduced.

Reprinted from Models for HRD Practice. Copyright 1989 by the American Society for Training \& Development. Reprinted with permission for this one time usage. All rights reserved.

Thank you for your professional interest in our publications. ASTD is pleased to be of service to you.

Sincerely,

Kathie R. St.Clair

Publications Project Coordinator 
APPENDIX G

RESPONSES TO

SURVEY QUESTION \#27 
APPENDIX G

\section{Responses to Survey Question \#27}

\section{Q27. What changes do you expect to occur in human resource development at your institution by the year 2010?}

- Greater integration with University mission, helping to lead change and measure effectiveness of change. More visibility with regard to job re-training.

- More programming in executive development for VPs, Deans and major Directors. Meaningful supervisory development offerings. More quality programming in team building and developing interpersonal skills.

- HR will be involved more than ever in strategic planning. It will also become more entrepreneurial, while being expected to offer more, and less traditional services to the campus community. There will be greater focus on employee development.

- Web-based and/or other forms of computer-based training. More extensive use of teleconferencing. Electronic records management (exclusively).

- Greater flexibility in providing options for staffing needs. Greater emphasis on customer service.

- More demand for training specific to individual's needs (customized for specific areas of improvement). More emphasis on alternative training methods (computer-based, videos, etc.) and less emphasis on instructor-led training.

- The development and implementation of a formalized, competency-based training curriculum available to every level of employee, i.e. support staff, supervisors, faculty, etc.

- We will need to expand our efforts significantly within the next decade. The Information Technology needs alone will cause tremendous growth in this area of Human Resources. We are beginning to understand the tremendous investment we must make and be willing to expand in HRD over the next decade.

- The HRD role is relatively new at our institution, hence the noted expectation of increases in emphasis on the specified roles.

- Operating at a more strategic level.

- The automation of many HR functions will reduce routine paper processes and staff. Highly skilled HR staff will perform non-traditional consulting activities, e.g. strategic planning, management, and forecasting.

- I expect to see an increased emphasis on workforce development and technology in HR. Another hot topic will be organizational change as we face substantial turnover in upper level personnel. I think HR will continue to be a support service and will decrease its command and control functions. 
- Much more emphasis on computer-based and web-based training programs.

- I expect increasing reliance on technology to allow staff freedom to deal with employees.

- A shift from Administrator and Manager of HR functions to emphasizing and supporting change in organizational behavior through research, designing new programs, presenting educational and training programs, and evaluating results.

- (1) Beginning stages of implementing a new "PeopleSoft" HR/Payroll, Student Life, totally integrated computer software. Will totally change the way we process HR/Payroll transactions. (2) Decentralize many administrative decision making processes to lowest level of the organization possible.

- Greater emphasis on partnership role between HR and major organizational units, particularly in planning, leadership development, succession planning, and compensation management.

- Increase in resources to allow more individual career development advising. 